\title{
How relevant is the deposition of mercury onto snowpacks? - Part 2: A modeling study
}

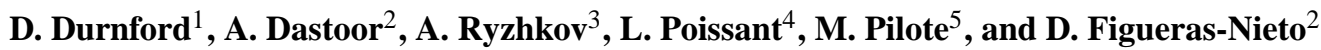 \\ ${ }^{1}$ Independent researcher, 3031 Cedar Avenue, Montreal, QC, H3Y 1Y8, Canada \\ ${ }^{2}$ Air Quality Research Division, Environment Canada, 2121 TransCanada Highway, Dorval, QC, H9P 1J3, Canada \\ ${ }^{3}$ Independent researcher, 4998 Maisonneuve West, Westmount, QC, H3Z 1N2, Canada \\ ${ }^{4}$ Atmospheric Toxic Processes Section, Environment Canada, 105 McGill St., Montreal, QC, H2Y 2E7, Canada \\ ${ }^{5}$ Fluvial Ecosystem Research Section, Environment Canada, 105 McGill St., Montreal, QC, H2Y 2E7, Canada
}

Correspondence to: A. Dastoor (ashu.dastoor@ec.gc.ca)

Received: 7 December 2011 - Published in Atmos. Chem. Phys. Discuss.: 26 January 2012

Revised: 28 September 2012 - Accepted: 1 October 2012 - Published: 11 October 2012

\begin{abstract}
An unknown fraction of mercury that is deposited onto snowpacks is revolatilized to the atmosphere. Determining the revolatilized fraction is important since mercury that enters the snowpack meltwater may be converted to highly toxic bioaccumulating methylmercury. In this study, we present a new dynamic physically-based snowpack/meltwater model for mercury that is suitable for large-scale atmospheric models for mercury. It represents the primary physical and chemical processes that determine the fate of mercury deposited onto snowpacks. The snowpack/meltwater model was implemented in Environment Canada's atmospheric mercury model GRAHM. For the first time, observed snowpack-related mercury concentrations are used to evaluate and constrain an atmospheric mercury model. We find that simulated concentrations of mercury in both snowpacks and the atmosphere's surface layer agree closely with observations. The simulated concentration of mercury in both in the top $30 \mathrm{~cm}$ and the top $150 \mathrm{~cm}$ of the snowpack, averaged over 2005-2009, is predominantly below $6 \mathrm{ng} \mathrm{L}^{-1}$ over land south of $66.5^{\circ} \mathrm{N}$ but exceeds $18 \mathrm{ng} \mathrm{L}^{-1}$ over sea ice in extensive areas of the Arctic Ocean and Hudson Bay. The average simulated concentration of mercury in snowpack meltwater runoff tends to be higher on the Russian/European side ( $>20 \mathrm{ng} \mathrm{L}^{-1}$ ) of the Arctic Ocean than on the Canadian side $\left(<10 \mathrm{ng} \mathrm{L}^{-1}\right)$. The correlation coefficient between observed and simulated monthly mean atmospheric surface-level gaseous elemental mercury (GEM) concentrations increased significantly with the inclusion of the new snowpack/meltwater model at two of the three stations (midlatitude, subarctic) studied and remained constant
\end{abstract}

at the third (arctic). Oceanic emissions are postulated to produce the observed summertime maximum in concentrations of surface-level atmospheric GEM at Alert in the Canadian Arctic and to generate the summertime volatility observed in these concentrations at both Alert and Kuujjuarapik on subarctic Hudson Bay, Canada. We find that the fraction of deposited mercury that is revolatilized from snowpacks increases with latitude from $39 \%$ between 30 and $45^{\circ} \mathrm{N}$, to $57 \%$ from 45 to $60^{\circ} \mathrm{N}, 67 \%$ from 60 to $66.5^{\circ} \mathrm{N}$, and $75 \%$ polewards of $66.5^{\circ} \mathrm{N}$ on an annual basis. Combining this latitudinal gradient with the latitudinally increasing coverage of snowpacks causes yearly net deposition as a fraction of gross deposition to decrease from $98 \%$ between 30 and $45^{\circ} \mathrm{N}$ to $89 \%$ between 45 and $60^{\circ} \mathrm{N}, 73 \%$ between 60 and $66.5^{\circ} \mathrm{N}$, and $44 \%$ within the Arctic Circle. The yearly net deposition and net accumulation of mercury at the surface within the Arctic Circle north of $66.5^{\circ} \mathrm{N}$ are estimated at 153 and $117 \mathrm{Mg}$, respectively. We calculate that 58 and $50 \mathrm{Mg}$ of mercury are deposited annually to the Arctic Ocean directly and indirectly via melting snowpacks, respectively. For terrestrial surfaces within the Arctic Circle, we find that 29 and $16 \mathrm{Mg}$ of mercury are deposited annually directly and indirectly via melting snowpacks, respectively. Within the Arctic Circle, multi-season snowpacks on land and over sea ice gained, on average, an estimated 0.1 and $0.4 \mathrm{Mg} \mathrm{yr}^{-1}$ mercury, respectively, from 2000-2005. The developed snowpack/meltwater model can be used for investigating the impact of climate change on the snowpack/atmosphere exchange of mercury. 


\section{Introduction}

Mercury is emitted by anthropogenic processes as gaseous elemental mercury (GEM), reactive gaseous mercury (RGM) and oxidized mercury adsorbed onto particles (PHg). GEM is also emitted from terrestrial and aquatic surfaces from natural sources and through the revolatilization of previouslydeposited mercury. Once in the atmosphere, mercury is transported, undergoes chemical reactions and is deposited. A fraction of the mercury that is deposited onto snowpacks is revolatilized rapidly (Lalonde et al., 2002). The fraction of mercury retained by snowpacks may be transported by the snowpack meltwater runoff to aquatic environments such as oceans, freshwater wetlands and peatlands where methylation can occur (Loseto et al., 2004; Goulet et al., 2007; Mitchell et al., 2008a; Sunderland et al., 2009). Since methylmercury is a potent bioaccumulating neuro-toxin and since a high proportion of the Aboriginal peoples' diet in Arctic countries consists of country foods that include large marine mammals and fish (Van Oostdam et al., 2005), the fate of mercury deposited onto snowpacks is an issue of great concern.

In order to limit the amount of mercury bioaccumulated by marine life, its sources must be well understood. In their mass budget of total mercury for the Arctic Ocean, Outridge et al. (2008) found that the net deposition of atmospheric mercury was the single largest source $(48 \%)$ of total mercury in the Arctic Ocean. The magnitude of this contribution was considered highly uncertain given that atmosphere/cryosphere and atmosphere/ocean mercury fluxes were not well understood.

To date, the precise fraction of mercury that is revolatilized from snowpacks has been hotly debated. St. Louis et al. (2005), Kirk et al. (2006), St. Louis et al. (2007) and Hedgecock et al. (2008) suggested that net deposition associated with high-latitude springtime Atmospheric Mercury Depletion Events (AMDEs) is low or insignificant. Similarly, Outridge et al. (2008) concluded that there is no firm evidence that AMDEs exert a significant influence on mercury concentrations in the Arctic Ocean. However, Lindberg et al. (2002), Dommergue et al. (2003), Loseto et al. (2004), Bargagli et al. (2005), Steffen et al. (2005), Faïn et al. (2007), Brooks et al. (2008a), Douglas et al. (2008), Johnson et al. (2008), Mitchell et al. (2008b), Hirdman et al. (2009), and Dommergue et al. (2010), who conducted field campaigns at a variety of polar and lower latitudes, all determined that mercury deposited onto snowpacks was only partially revolatilized and could have an important impact on the environment. The partial revolatilization was reported for mercury deposited both in and not in association with AMDEs.

A further indication of the ability of snowpacks to retain deposited mercury is provided by long-term cryospheric records. Although concentrations of mercury in firn and ice cores can be extremely low or undetectable (Boutron et al., 1998; Larose et al., 2010), they can also be significant in the mean (Faïn et al., 2008), or during climatologically cold periods (Jitaru et al., 2009), or in individual layers (Schuster et al., 2002; Planchon et al., 2004; Witherow and Lyons, 2008). Moreover, even in locations where mercury concentrations in long-term cryospheric records are low, the seasonal accumulation of mercury and its delivery to the meltwater may be important.

Processes involving mercury within the snowpack are complex. Since GEM is highly labile (Bartels-Rausch et al., 2008) it is likely revolatilized from the snowpack immediately. In contrast, there is strong evidence that $\mathrm{PHg}$ is retained by the snowpack (Balogh et al., 2000; Schuster et al., 2002; St. Louis et al., 2005; Cobbett et al., 2007; Loewen et al., 2007; Poulain et al., 2007a, b; Witherow and Lyons, 2008; Jitaru et al., 2009; Durnford and Dastoor, 2011). However, RGM that is deposited to the snowpack may be reduced and revolatilized. Reduction is primarily through photoreduction by UV-B radiation in the $305-320 \mathrm{~nm}$ wavelength range (Lalonde et al., 2003; Poulain et al., 2004; St. Louis et al., 2005; Dommergue et al., 2007; Faïn et al., 2007; Johnson et al., 2008; Sherman et al., 2010). Prior to revolatilization, the produced GEM may be reoxidized (Lalonde et al., 2003; Ferrari et al., 2004b; Poulain et al., 2004, 2007b; Mann et al., 2005; Lahoutifard et al., 2006; Lin et al., 2006; Dommergue et al., 2007; Faïn et al., 2006, 2007, 2008). Furthermore, halides stabilize oxidized mercury within the snowpack (Lalonde et al., 2003; Ferrari et al., 2004b; Faïn et al., 2006, 2008; Bartels-Rausch et al., 2011; Mann et al., 2011). Revolatilization is also less active under canopies than in adjacent open areas (Poulain et al., 2007b; Nelson et al., 2008). Although multiple factors are responsible (Fatnassi et al., 2006; Poulain et al., 2007b; Yue et al., 2008), the primary factor is likely the canopy's shadowing effect (Poulain et al., 2007a, b), which diminishes photoreduction. It also seems likely that mercury is rendered unavailable for emission through burial by fresh snowfalls (Witherow and Lyons, 2008; Dommergue et al., 2010).

The GEM that forms within the snowpack must be transported to the pack's surface prior to revolatilization. Several field and laboratory studies have suggested that GEM is emitted from the top $\sim 2$ centimeters of the snowpack (Brooks et al., 2008a; Johnson et al., 2008; Dommergue et al., 2007; Faïn et al., 2007). The transport is effected by molecular and turbulent diffusions (Albert and Shultz, 2002). The former transport is slow but ubiquitous (Albert and Shultz, 2002). The latter transport, which is also known as snowpack ventilation, is forced by atmospheric surface-level turbulence. Existing turbulence may be imported or induced locally by flow over rough terrain and radiationally-forced thermal instability (Kuhn, 2001; Albert and Shultz, 2002; Anderson and Neff, 2008).

At the onset of snowmelt, the rates of photoreduction and revolatilization of GEM to the atmosphere increase significantly (Dommergue et al., 2003; Faïn et al., 2007; Sommar et al., 2007; Brooks et al., 2008b; Douglas et al., 2008), causing 
a surge in the concentration of atmospheric surface-level GEM. Simultaneously, oxidized mercury is rapidly transferred from the snowpack to the meltwater's ionic pulse. The ionic pulse (Bales et al., 1990; Bishop et al., 1995; Allan et al., 2001; Kuhn, 2001; Lindberg et al., 2002; Dommergue et al., 2003, 2010), which lasts a few days (Bales et al., 1990; Bishop et al., 1995; Dommergue et al., 2003), contains ionic concentrations that are higher than in the snowpack and that are 5-10 times higher than average meltwater concentrations (Bales et al., 1989, 1990).

Field data demonstrate that concentrations of cryospheric mercury and the fate of mercury deposited onto snowpacks are highly heterogeneous (Garbarino et al., 2002; Kirk et al., 2006; Poulain et al., 2007a, b; St. Louis et al., 2007; Brooks et al., 2008b; Johnson et al., 2008; Nelson et al., 2008). Moreover, field data are only valid at the location and time of observation. Hence, extrapolating results from individual studies either temporally or spatially is difficult (Steffen et al., 2008). Durnford and Dastoor (2011) compiled datasets of observed concentrations of cryospheric mercury. Durnford et al. (2012) used these datasets in a statistical study that explored relationships between snowpack-related mercury observations and the environment. These authors concluded that halogens within snowpacks exert a strong influence over mercury in snowpacks. In the absence of this influence, mercury deposition explains $84 \%, 52 \%, 52 \%$ and $20 \%$ of the variability in observed concentrations of mercury in surface snow, seasonal snowpacks, the snowpack meltwater's ionic pulse, and long-term snowpack-related records, respectively; the influence of other environmental factors seemingly strengthens over time.

Numerical models are useful in that they are able to estimate the fate of mercury deposited onto snowpacks over extended spatial and/or temporal scales. However, their usefulness depends on the accuracy of the representation of the processes involved. In a global three-dimensional model, Dastoor et al. (2008) described a representation of AMDEs, their associated deposition and the revolatilization of the deposited mercury. However, this representation was simplistic. Also in a global atmospheric mercury model, Holmes et al. (2010) constructed a snowpack reservoir to accumulate deposited mercury. Revolatilization was based on a set lifetime.

Concerning small-scale process models, Ferrari et al. (2004b) and Fain et al. (2008) modeled the diffusion of GEM in the interstitial air of snow. Faïn et al. (2009) used a diffusion model to deduce atmospheric GEM concentrations from 1940 to 2006 from concentrations of GEM in firn air. Poulain et al. (2007b) presented a mass balance for mercury in snowpacks that considered wet and dry depositions and throughfall as sources and revolatilization and snowmelt as sinks. Values of wet deposition, revolatilization and snowmelt were estimated from observations of wet deposition, the concentration of mercury in the springtime snowpack, and calculated rates of reduction under different canopies. The sum of dry deposition and throughfall was de- rived from these estimated values and the observed snowpack mercury concentration.

Thus, no one, to our knowledge, has yet simulated the fate of mercury deposited onto snowpacks in anywhere near its full complexity. In the present study, a dynamic model that predicts the fate of mercury deposited onto snowpacks according to the local physical and chemical environments is presented (Sect. 2) and its performance verified (Sect. 3). Section 4 provides a summary and the primary conclusions. Suggestions for future work are presented in Sect. 5. Given the described snowpack/meltwater model's dynamism, it is well suited to numerical studies on the impact on mercury net deposition from changing climate and/or emission scenarios.

\section{Model}

\subsection{GRAHM}

GRAHM is an Eulerian model built on top of Environment Canada's Global Environmental Multiscale - Global Deterministic Prediction System (GEM-GDPS). GEM-GDPS is an atmospheric general circulation model. It is used to produce Environment Canada's daily weather forecasts. The GEMGDPS utilises a semi-Lagrangian advection scheme to promote stability, and an implicit time scheme to control high frequency oscillations (Côté et al., 1998a, 1998b). The radiative transfer scheme, which is based on Fouquart and Bonnel (1980) and Garand and Mailhot (1990), is calculated every $1.5 \mathrm{~h}$. Stratiform precipitation is calculated by a Sundqvistbased scheme (Sundqvist, 1978). Deep convective precipitation is calculated by a Kain-Fritsch scheme (Kain and Fritsch, 1990). The turbulent mixing of meteorological and mercury species in the boundary layer is based on turbulent kinetic energy. Both turbulent kinetic energy and cloud liquid water/ice content are prognostic model variables.

Meteorological and mercury processes are fully integrated in the GRAHM online chemical transport model. At each timestep, mercury emissions are added to the atmospheric model concentrations, the meteorological processes are simulated, and the atmospheric mercury species are transported, transformed chemically and deposited. The simulations of the mercuric chemical transformations and depositional processes use information calculated by the meteorological component of the model during the same timestep, including boundary layer stability, the behaviour of cloud water/ice, and precipitation. GRAHM has been seen to perform well in past studies (Ryaboshapko et al., 2007a, b; Dastoor et al., 2008; Durnford et al., 2010).

In GRAHM, gaseous oxidation of mercury by ozone occurs throughout the atmosphere with a temperaturedependent rate constant following Hall (1995). The gaseous oxidation of mercury by halogens, including atomic and molecular chlorine and bromine as well as bromine oxide 
occurs in the marine boundary layer only. Rate constants are from Ariya et al. (2002), Raofie and Ariya (2003) and Donohoue et al. (2005). In the Arctic, atomic bromine is the primary oxidant followed by bromine oxide. Mercury is reduced in the aqueous phase photochemically and by the sulfite anion and the hydroperoxyl radical using rate constants from Xiao et al. (1994), Pehkonen and Lin (1998) and Van Loon et al. (2000). Global three-dimensional monthly climatological concentrations of oxidants and reductants are used.

Dry deposition is based on the resistance approach (Zhang et al., 2001, 2003). In the wet deposition scheme, GEM and RGM are partitioned between cloud droplets and air using a temperature-dependent Henry's law constant. Scavenging of GEM is only by cloud droplets, while RGM and PHg are scavenged by both cloud droplets and raindrops below cloud. $\mathrm{PHg}$ is the only mercury species that is scavenged by solid hydrometeors both in cloud and below cloud.

Atmospheric Mercury Depletion Events (AMDEs) are simulated in springtime at high latitudes (Dastoor et al., 2008). Three distinct processes are involved, the relative importance of which likely varies by location: (1) GEM undergoes significant oxidation, which involves representing springtime "bromine explosions" (Wennberg, 1999). These explosions are periodic, localized releases of oxidizing bromine species to the atmosphere; (2) the oxidized mercury produced is deposited onto snowpacks and subsequently revolatilized; 3) simultaneously, the mercury-depleted air masses are transported.

We use the global anthropogenic mercury emission fields produced by AMAP for 2005 (Pacyna et al., 2010). Nonanthropogenic terrestrial and oceanic emissions of GEM are based on the global mercury budget of Mason (2009). Terrestrial non-anthropogenic emissions are divided into direct natural emissions, and emissions of previously-deposited mercury. The former are distributed according to the natural geological enrichment of mercury. The latter are allocated according to the distribution of gross deposition of mercury for historic years. The ratios of simulated nonanthropogenic to anthropogenic emissions agree with published estimates for North America (Gbor et. al., 2007) and East Asia (Shetty et al., 2008). The seasonal and diurnal variations of terrestrial emissions are based on the leaf area index and incoming direct solar radiation, following Shetty et al. (2008). Ocean emissions occur in areas where gaps are found in the sea ice cover (Kirk et al., 2006; St. Louis et al., 2007) and atmospheric temperatures are at least $-4^{\circ} \mathrm{C}$; evasion decreases with temperature (Poissant et al., 2000; Andersson et al., 2008a). The variation of oceanic emissions by month introduces a further, implicit dependence on sea surface temperature.

\subsection{Snowpack/meltwater model}

The snowpack/meltwater model consists of two active snowpack layers overlying a burial layer. We track the exchange

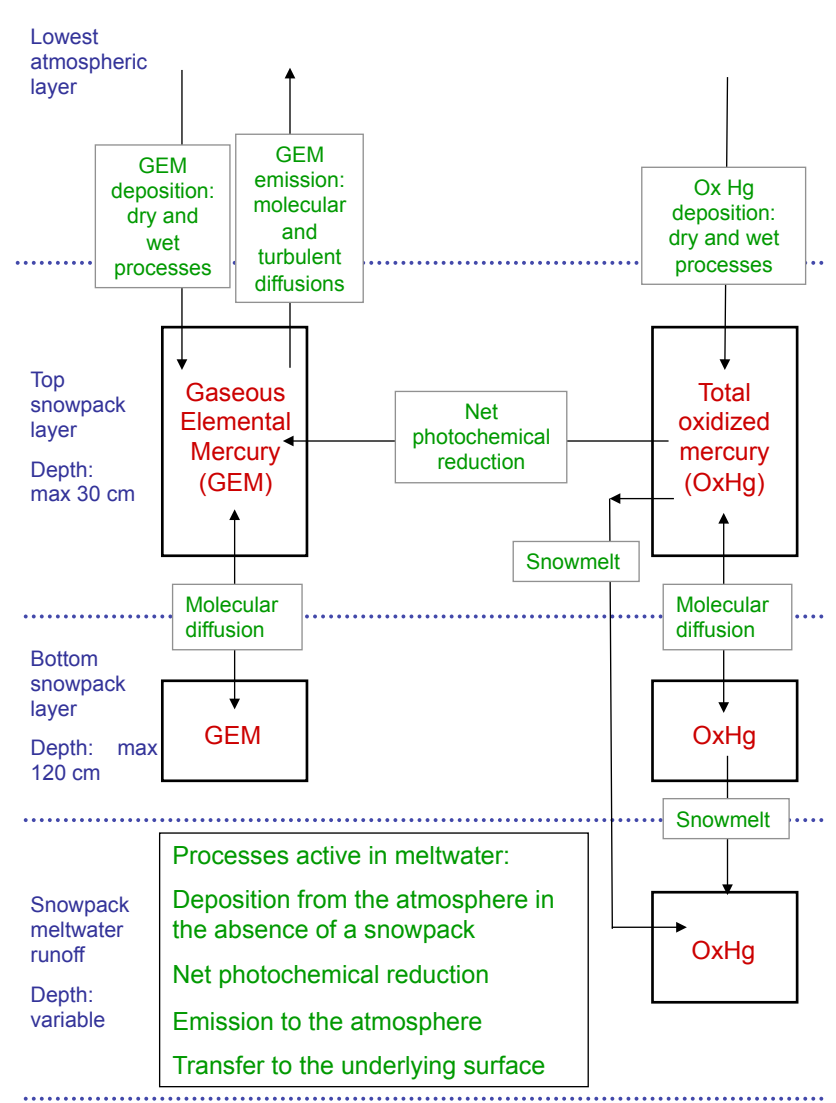

Fig. 1. A schematic of processes represented in the snowpack/meltwater model for mercury.

of mercury between the top snowpack layer and the atmosphere, and between the two active snowpack layers (Fig. 1). Once mercury is transferred to the inactive snowpack layer through snow accumulation, there is no further exchange of this mercury; it has been buried by fresh snowfalls (Witherow and Lyons, 2008; Dommergue et al., 2010). The model also includes a single layer of snowpack meltwater runoff, or meltwater that has exited the snowpack but that has not yet been absorbed by the underlying surface nor entered a larger body of water.

The minimum depth of both the top snowpack layer and the snowpack meltwater runoff is $2 \mathrm{~cm}$. At lesser depths, the effect of the snowpack or runoff on fluxes of mercury between the underlying surface and the atmosphere is assumed to be minimal. The maximum depth of the top snowpack layer is $30 \mathrm{~cm}$. With a shallower top layer, the simulated revolatilization of mercury via turbulent diffusion generates unrealistic spikes in the concentration of atmospheric GEM. However, a deeper top layer is undesirable given that Ferrari et al. (2004b) reported that, at Station Nord in Greenland, little of the GEM that is produced at depths of 20 to $40 \mathrm{~cm}$ is subsequently emitted. It is possible that the transfer of mercury to the atmosphere during their study was primarily via molecular diffusion. The maximum depth of the bottom 
active snowpack layer (hereafter the bottom layer) is $120 \mathrm{~cm}$. Snowpack ventilation can, depending on the snowpack's permeability and the strength of the ventilation-driving turbulence (Kuhn, 2001; Albert and Shultz, 2002; Domine et al., 2008), extend to depths of 50-100 cm (Domine et al., 2008). Molecular diffusion, which is active at even greater depths (Faïn et al., 2009), continuously transfers mercury vertically.

Mercuric chemical transformations have been observed at a depth of $1.02 \mathrm{~m}$ (Dommergue et al., 2003). However, given that GEM is not consistently emitted at depths greater than $30 \mathrm{~cm}$ (Ferrari et al., 2004b), mercury is transformed chemically only in the top layer of the snowpack model. In contrast, since the depth of the snowpack meltwater runoff is expected to be less than $10 \mathrm{~cm}$, a single layer is provided. Mercury is transformed chemically in this layer and the GEM produced is transferred to the atmosphere.

As suggested by Fig. 1, the concentration of GEM in the top snowpack layer varies according to Eq. (1):

$d / d t\left(\mathrm{G}_{\mathrm{top}}\right)=\mathrm{Dep}_{\mathrm{Gatm}}+\mathrm{NP}_{\text {Otop }}-\mathrm{Emi}_{\mathrm{Gtop}}+\mathrm{Diff}_{\mathrm{Gbot}}-\mathrm{SMlt}_{\mathrm{Gtop}}$

where Depatm is deposition of atmospheric GEM

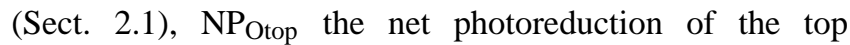
snowpack layer's oxidized mercury, Emi Gtop $_{\text {the emission }}$ of GEM from the top snowpack layer to the atmosphere, Diff $_{\text {Gbot }}$ the diffusion of GEM from the bottom to the top snowpack layer, and SMlt ${ }_{\text {Gtop }}$ the transfer of GEM from the top snowpack layer to the atmosphere during snowmelt. For the sake of simplicity, conversion factors are not shown in this or any of the following equations.

Similarly, the concentration of oxidized mercury in the top snowpack layer is defined by Eq. (2):

$d / d t\left(\mathrm{O}_{\text {top }}\right)=$ Depoatm $_{-}-\mathrm{NP}_{\text {Otop }}+$ Diff $_{\text {Obot }}-\mathrm{SMlt}_{\text {Otop }}$

where Depoatm is deposition of atmospheric oxidized mercury (Sect. 2.1), Diff Obot the diffusion of oxidized mercury from the bottom to the top snowpack layer, and SMltotop the transfer of oxidized mercury from the top snowpack layer to the snowpack meltwater during snowmelt. Oxidized mercury within the snowpack currently combines both RGM and PHg since little information is available on mercury's adsorption to and desorption from particles within snowpacks. We do know that spiking snow with salt decreases the fraction of mercury that is associated with particles (Mann et al., 2011).

The concentrations of GEM and oxidized mercury in the bottom snowpack layer are defined by Eqs. (3) and (4), respectively:

$$
d / d t\left(\mathrm{G}_{\mathrm{bot}}\right)=- \text { Diff }_{\mathrm{Gbot}}
$$

$d / d t\left(\mathrm{O}_{\text {bot }}\right)=-$ Diff $_{\text {Obot }}$

The relative simplicity of Eqs. (3) and (4) versus Eqs. (1) and (2) reflects the fact that in the bottom layer no chemical conversions are represented, as discussed above.
Concerning mercuric chemical transformations, it is known that oxidized mercury is reduced within the snowpack both photolytically (Lalonde et al., 2003; Poulain et al., 2004; St. Louis et al., 2005; Dommergue et al., 2007; Faïn et al., 2007; Johnson et al., 2008; Sherman et al., 2010) and in the dark (Lalonde et al., 2003; Ferrari et al., 2004b, 2008; Dommergue et al., 2007; Faïn et al., 2007; Mann et al., 2011). GEM is also oxidized within the snowpack in the presence of sunlight (Ferrari et al., 2004b; Poulain et al., 2004; Mann et al., 2005; Faïn et al., 2008) and in the dark (Poulain et al., 2004, 2007b; Faïn et al., 2008). Furthermore, halides stabilize oxidized mercury within the snowpack (Lalonde et al., 2003; Ferrari et al., 2004b; Faïn et al., 2006, 2008). However, very little, if anything, is known about either the reaction rate or the reactants of the individual reactions. Therefore, the model only represents the net photoreduction of oxidized mercury, which is described as follows:

$\mathrm{NP}_{\text {Otop }}=\mathrm{C}_{\text {ins }} \mathrm{C}_{\text {ox }} \mathrm{k}_{\mathrm{NP}} \mathrm{O}_{\text {top }}$

where $\mathrm{C}_{\mathrm{ins}}$ is the coefficient describing the availability of solar radiation, or insolation, $\mathrm{C}_{\mathrm{ox}}$ the coefficient describing the snowpack's content of oxidants and stabilizing halides, and $\mathrm{k}_{\mathrm{NP}}$ the basic rate of net photoreduction. The magnitude of both $\mathrm{C}_{\mathrm{ins}}$ and $\mathrm{C}_{\mathrm{ox}}$ is constrained to lie between zero and unity.

The greatest sensitivity in the snowpack model, by far, is to the value of $\mathrm{C}_{\mathrm{ins}}$. Simplistic definitions of $\mathrm{C}_{\mathrm{ins}}$ produce a significantly overenergetic revolatilization of mercury from high-latitude snowpacks during spring. Thus, the BouguerLambert law (King and Simpson, 2001) was used to calculate the magnitude of the actinic flux at snowpack depth d:

$\mathrm{AF}(\mathrm{d})=\cos (\mathrm{Z}) \times \mathrm{FS} \times \exp (-\mathrm{d} / \varepsilon(\lambda))$

where $\mathrm{Z}$ represents the solar zenith angle, FS the solar flux absorbed at the surface, and $\varepsilon(\lambda)$ the $e$-folding depth at radiation wavelength $\lambda$. The product of $\cos (\mathrm{Z})$ and FS yields the magnitude of the downwelling component of the solar radiation as it penetrates the surface of the snowpack, or the incident actinic flux. The $e$-folding depth is the depth at which the actinic flux is $1 / e$ of its incident value (Perovich, 2007). The actinic flux is the amount of solar radiation reaching a given point, integrated over a sphere. Since the actinic flux depends on the solar zenith angle (Eq. (6)), the amount of radiation available within the snowpack to drive net photoreduction increases only gradually at high latitudes during spring. This gradual increase is crucial for the realistic, non-overenergetic revolatilization of mercury pooled in the snow during polar night (Steen et al., 2009) or deposited during springtime AMDEs (Lu et al., 2001; Berg et al., 2003; Ariya et al., 2004; Christensen et al., 2004; Heidam et al., 2004; Skov et al., 2004; Ferrari et al., 2005; Travnikov, 2005; Brooks et al., 2006; Kirk et al., 2006; Constant et al., 2007; Sommar et al., 2007; Johnson et al., 2008; Steffen et al., 2008). 
In the snowpack model, the value of $\mathrm{C}_{\mathrm{ins}}$ in $\mathrm{Eq}$. (5) is equal to, within the above-mentioned zero to unity constraint, the value of $A F(d)$, as calculated by Eq. (6), with $d$ set to half the depth of the top snowpack layer. The values of $Z$ and FS in Eq. (6) are provided by GRAHM. The e-folding depth of a snowpack, which is determined by the radiation wavelength of interest and snowpack characteristics (King and Simpson, 2001; Galbavy et al., 2007; Perovich, 2007), can range from 1 to $\sim 50 \mathrm{~cm}$ for wavelengths of 300 to $400 \mathrm{~nm}$ in a variety of snowpack types (Durnford and Dastoor, 2011). We determined $7.5 \mathrm{~cm}$ to be an appropriate value for $\varepsilon(\lambda)$ in Eq. (6), as it represents an average e-folding depth over a variety of snowpack types for the wavelengths of greatest interest for the photoreduction of mercury in snowpacks, or 305 to $320 \mathrm{~nm}$ (Dommergue et al., 2007).

The Bouguer-Lambert law is valid only below the very top layer of a snowpack. The very top layer, which is up to $2 \mathrm{~cm}$ thick for UV radiation (Lee-Taylor and Madronich, 2002; Peterson et al., 2002), is characterized by an actinic flux that is up to $\sim 4$-fold greater than the magnitude of the incident downwelling UV radiation (Warren, 1982; King and Simpson, 2001; Simpson et al., 2002). This high actinic flux layer, combined with molecular diffusion, likely explains why several studies determined that GEM is emitted from the top 2-3 centimeters of the snowpack (Dommergue et al., 2007; Faïn et al., 2007; Brooks et al., 2008a; Johnson et al., 2008). However, the emission of GEM from such a thin source layer likely occurs only under fairly calm conditions; snowpack ventilation, which flushes mercury from deeper in the snowpack into the atmosphere and which is driven by atmospheric turbulence, can, as mentioned above, extend to depths of 50$100 \mathrm{~cm}$. The snowpack model does not currently represent the complex high actinic flux layer and its ability to promote revolatilization. The neglect of this layer is likely compensated for by the 30-cm depth of the top snowpack layer, given that Ferrari et al. (2004b) reported that little GEM was emitted from depths of $20-40 \mathrm{~cm}$ at Station Nord, Greenland.

The value of $\mathrm{C}_{\mathrm{ox}}$ in Eq. (5) is set to unity except over first-year sea ice and under canopies. Over first-year sea ice, snowpacks can contain significant amounts of oxidizing and stabilizing halogen species (Simpson et al., 2007a, b). Therefore, for snowpacks over first-year sea ice, which is here defined as being less than $3 \mathrm{~m}$ thick, $\mathrm{C}_{\mathrm{ox}}$ is set to $0.97 . C_{o x}$ is valued at unity in snowpacks over multi-year sea ice in recognition of these packs' lower concentrations of halogen species (Yang et al., 2010). Under coniferous and mixed coniferous/deciduous canopies, $\mathrm{C}_{\mathrm{ox}}$ is valued at 0.97 and 0.98 respectively, based on results from Poulain et al. (2007b).

The value of Eq. (5)'s $k_{N P}$ is based on rates of net photoreduction of snowpack mercury from Durnford and Dastoor (2011). These rates, which were calculated from published reports of field studies, ranged from $1.9 \times 10^{-9}$ to $1.7 \times 10^{-4} \mathrm{~s}^{-1}$. The wide range of rates likely reflects differing availabilities of solar radiation and varying loads of oxidants and stabilizing halides in the snowpacks examined during the field studies. It may also reflect variations in the chemical transformations occurring at the different locations. The value of $\mathrm{k}_{\mathrm{NP}}$ used in the snowpack model is $7.0 \times 10^{-7} \mathrm{~s}^{-1}$, which falls within the calculated range of rates. This value, in combination with $\mathrm{C}_{\mathrm{ins}}$ and $\mathrm{C}_{\mathrm{ox}}$, yields the most realistic results over all latitudes: higher rates yield overenergetic surges in emission at high latitudes, while lower rates yield overly high concentrations of mercury in the snowpack at all latitudes and depress simulated concentrations of atmospheric GEM noticeably at midlatitudes.

In Eq. (5), several assumptions are made. It is believed that ionic solutes and impurities in snow are generally located toward the outside of the snow grain and are, therefore, available for chemical reactions (Kuhn, 2001; Albert and Shultz, 2002; Dommergue et al., 2003). Following this reasoning, and in the absence of further guidance, we assume that molecules of oxidized mercury occupy no more than a monolayer on the outer surface of snow grains. In this configuration they can be photoreduced without interference and the resulting GEM molecules can be transferred to the interstitial air of snow easily. Furthermore, net photoreduction is then independent of the specific surface area of the snowpack. We also assume that all GEM within the snowpack resides in the interstitial air, while all oxidized mercury resides on the snow grains, given that the former is hydrophobic and the latter hydrophilic. We further assume, in the absence of guidance from the literature, that there is an unlimited supply of reductants within the snowpack.

Concerning the transfer of mercury from the snowpack to the atmosphere, the diffusive flux of GEM from the top snowpack layer to the lowest atmospheric layer is defined as:

$\mathrm{Emi}_{\mathrm{Gtop}}=\mathrm{k}_{\mathrm{topA}} \times\left(\mathrm{G}_{\mathrm{top}}-\mathrm{G}_{\mathrm{atm}}\right)$

where $\mathrm{k}_{\mathrm{topA}}$ is the transfer coefficient from the top snowpack layer, and $\mathrm{G}_{\mathrm{atm}}$ the concentration of GEM in the surface layer of the atmosphere. $\mathrm{k}_{\mathrm{topA}}$ is defined as:

$\mathrm{k}_{\text {topA }}=\left(\mathrm{D}_{\text {mol }}+\mathrm{D}_{\mathrm{turb}}\right) / \mathrm{L}$

where $D_{\text {mol }}$ and $D_{\text {turb }}$ are, respectively, the effective rates of molecular and turbulent diffusions of GEM within the snowpack, and $\mathrm{L}$ is the characteristic path length. $\mathrm{L}$ is valued at $d_{\text {top }} / 2$, where $d_{\text {top }}$ is the depth of the top snowpack layer (Hansen et al., 2006). The value of $D_{m o l}$ is set to $6.0 \times 10^{-6} \mathrm{~m}^{2} \mathrm{~s}^{-1}$ (Albert and Shultz, 2002; Fain et al., 2008). The value of $\mathrm{D}_{\text {turb }}$ is calculated as follows:

$\mathrm{D}_{\text {turb }}=1.0 \times 10^{-5} \times \mathrm{C}_{\mathrm{TKE}} \times \mathrm{TKE}_{\mathrm{atm}}$

where $\mathrm{C}_{\mathrm{TKE}}$ is the turbulent kinetic energy coefficient, and $\mathrm{TKE}_{\text {atm }}$ is atmospheric surface-level turbulent kinetic energy. The value of $\mathrm{C}_{\mathrm{TKE}}$ is set to unity except for snowpacks under coniferous and mixed coniferous/deciduous canopies. Under the former and latter canopy types it is set to 0.4 and 
0.6, respectively; canopies absorb momentum (Fatnassi et al., 2006; Yue et al., 2008). The value of $\mathrm{TKE}_{\text {atm }}$ used in Eq. (9) is provided by GRAHM. The use of TKE $\mathrm{atm}_{\text {elim- }}$ inates the need to represent explicitly within the snowpack model the mechanisms that generate snowpack-ventilating atmospheric surface-level turbulence. These mechanisms include wind blowing over a rough surface and thermal instability (Kuhn, 2001; Albert and Shultz, 2002; Anderson and Neff, 2008; Durnford and Dastoor, 2011).

The bidirectional diffusive transfer of GEM between the two snowpack layers is driven by molecular diffusion alone:

Diff $_{\text {Gbot }}=\mathrm{k}_{\text {snow }} \times\left(\mathrm{G}_{\text {bot }}-\mathrm{G}_{\text {top }}\right)$

where $\mathrm{k}_{\text {snow }}$ is the transfer coefficient. Given the current lack of knowledge, oxidized mercury is transferred bidirectionally between the two snowpack layers as per the transfer of GEM. The calculation of $\mathrm{k}_{\text {snow }}$ in Eq. (10) is analogous to the calculation of the bidirectional transfer coefficient for snowpack/atmosphere (Hansen et al., 2006) and water/atmosphere (Loux, 2001) fluxes:

$\mathrm{k}_{\text {snow }}^{-1}=\mathrm{k}_{\text {topS }}^{-1}+\mathrm{k}_{\text {botS }}^{-1}$

where $\mathrm{k}_{\mathrm{topS}}$ and $\mathrm{k}_{\mathrm{botS}}$ are the transfer coefficients from the top and bottom snowpack layers, respectively. $\mathrm{k}_{\text {tops }}$ in Eq. (11) is defined as:

$\mathrm{k}_{\mathrm{topS}}=\mathrm{D}_{\mathrm{mol}} \mathrm{L}^{-1}$

where $\mathrm{D}_{\mathrm{mol}}$ and $\mathrm{L}$ have the same values as in Eq. (8). $\mathrm{k}_{\mathrm{botS}}$ is calculated as per Eq. (12), but with a value for $L$ of $d_{b o t} / 2$, where $\mathrm{d}_{\mathrm{bot}}$ is the depth of the bottom snowpack layer.

In a melting snowpack, following Dommergue et al. (2003), all GEM contained in the melted portion is transferred to the atmosphere while oxidized mercury is transferred to the snowpack meltwater. These processes are represented by Eq. (1)'s SMlt ${ }_{\text {Gtop }}$ and Eq. (2)'s SMltotop. The uptake of mercury by the snowpack meltwater is seen to be $\sim 2.4$ times higher than the snowpack's mean mercury concentration (Bales et al., 1990; Kuhn, 2001). This process is referred to as the ionic pulse (Bales et al., 1989, 1990; Bishop et al., 1995; Allan et al., 2001; Kuhn, 2001; Lindberg et al., 2002; Dommergue et al., 2003, 2010). Since it is believed that oxidized mercury resides primarily on the outer surface of the snow grains (see above), it is likely flushed out of the pack at the onset of snowmelt as the outer surface of the grains melt. Thus, following observations and theoretical considerations, the ionic pulse is modeled by transferring 2.4 times the oxidized mercury content of the melted portion of the top snowpack layer to the meltwater by drawing oxidized mercury from the rest of the snowpack layer. Consequently, this process affects the concentration of oxidized mercury in the unmelted portion of the top snowpack layer.

The model's treatment of meltwater as it exits the snowpack varies according to the underlying surface. Over soilcovered surfaces, a fraction of the exiting meltwater is immediately absorbed, with its mercury content, into the soil.
The remaining fraction of the exiting meltwater enters the snowpack meltwater runoff. The meteorological component of GRAHM calculates the respective fractions. Over icecovered bodies of water and glaciers and in urban areas, all meltwater exiting the snowpack enters the runoff immediately. The meltwater model represents the net photochemical reduction of oxidized mercury in runoff, the emission of GEM to the atmosphere, and the transfer of the runoff and its mercury content to the underlying surface (Fig. 1). Once the snowpack has melted, atmospheric mercury is deposited onto the runoff. The meltwater model does not include rainwater runoff, which might dilute the snowpack meltwater runoff, as we are only interested in the mercury budget of the snowpack and its meltwater runoff.

The meltwater model's calculation of the net photoreduction of oxidized mercury in runoff is similar to Eq. (5). Considering that the outer surface of snow grains, where impurities tend to be located (see above), is a quasi-liquid medium (Abbatt, 2003), whereas the runoff is an actual liquid, it is not unreasonable that $\mathrm{k}_{\mathrm{NP}}$ be identical in both media. The calculation of $\mathrm{C}_{\mathrm{ox}}$ is also identical in the snowpack and meltwater models; the runoff presumably contains the same oxidants and stabilizing halides as the parent snowpack. In the meltwater model, $\mathrm{C}_{\text {ins }}$ is valued at unity in the presence of sunlight, and zero otherwise. Since the depth of the runoff is presumed to be less than $10 \mathrm{~cm}$, a simple formulation for $\mathrm{C}_{\mathrm{ins}}$ is considered sufficient.

The emission of GEM from the runoff occurs only under melting conditions to prevent emission from temporarily refrozen runoff. Melting conditions are defined as an atmospheric temperature greater than $-4^{\circ} \mathrm{C}$ in the presence of sunlight or greater than $0{ }^{\circ} \mathrm{C}$ at any time. The calculation of the emission is similar to Eq. (7). The definition of the transfer coefficient, $\mathrm{k}_{\mathrm{runA}}$, was adapted from Soerensen et al. (2010) for fresh water at $0{ }^{\circ} \mathrm{C}$ using data from Wilke and Chang (1955), Poissant et al. (2000), Loux (2001), and Andersson et al. (2008a):

$\mathrm{k}_{\mathrm{runA}}=9.7 \times 10^{-4}\left|\boldsymbol{v}_{10}\right|^{1.64}$

where $\left|\boldsymbol{v}_{10}\right|$ represents the atmospheric 10-m wind speed.

The transfer to the underlying surface of the runoff's mercury content depends on the nature of the surface. Over soil and glaciers, the runoff and its mercury content are assumed to be absorbed by the underlying surface or a larger body of water within $48 \mathrm{~h}$. In contrast, over ice-covered bodies of water in the presence of melting conditions, which are defined above, the runoff is assumed arbitrarily to escape to the underlying body of water through cracks in the ice at a rate of $3 \mathrm{~mm}$ per $12 \mathrm{~h}$. At atmospheric temperatures below $-10^{\circ} \mathrm{C}$, all runoff over ice (glaciers or sea/lake ice) is assumed to refreeze and its mercury content is reabsorbed by the pack at the ice/snowpack interface (Poulain et al., 2007b; Larose et al., 2010). In urban areas, all runoff is assumed to be captured immediately by the drainage system. 


\subsection{Simulations}

We performed three simulations to test the performance of the snowpack/meltwater model: the base (BRun), snowocean (SORun) and snow (SRun) runs. BRun, SORun and SRun use identical versions of GRAHM (Sect. 2.1) apart from the treatment of snowpack and oceanic emissions. BRun uses an earlier version of the parameterization of the revolatilization of mercury deposited onto snowpacks (Dastoor et al., 2008). The revolatilization of mercury from snowpacks in SORun is calculated dynamically using the new snowpack/meltwater model (Sect. 2.2). Oceanic emissions are increased in SORun over those in BRun from May through August in the Hudson Bay area $\left(70^{\circ}\right.$ to $100^{\circ} \mathrm{W}, 50^{\circ}$ to $\left.66.5^{\circ} \mathrm{N}\right)$, the low Arctic $\left(66.5^{\circ}\right.$ to $\left.80^{\circ} \mathrm{N}\right)$, and the high Arctic (polewards of $80^{\circ} \mathrm{N}$ ). In SORun, the prescribed evasion varies by month and sector. It is activated in the presence of an incomplete sea ice cover and an atmospheric temperature of $-4^{\circ} \mathrm{C}$ or greater; sea ice appears to inhibit atmosphere/ocean fluxes while evasion is temperature-dependent (Kirk et al., 2006; Andersson et al., 2008a, 2008b). It was found that simulated and observed concentrations of atmospheric mercury (Sect. 3.2) agree best under a prescribed evasion that is strongest in the Hudson Bay area, followed by the High then Low Arctic. The prescribed evasion is activated later at higher latitudes compared to lower latitudes during spring as a result of the sea ice cover and atmospheric temperature requirements. The activated evasion increases with latitude in the Arctic as observed (Hirdman et al., 2009). The impact on atmospheric concentrations from oceanic emissions north of $66.5^{\circ} \mathrm{N}$ and from Hudson Bay is investigated in SRun by removing these emissions completely from May through August.

BRun, SRun and SORun use a global domain at a 1degree latitude-longitude horizontal resolution and a 30-min timestep. The vertical resolution is 28 levels prior to October, 2006 and 58 levels afterwards. The model top is constant at $10 \mathrm{hPa}$. The vertical resolution follows that of the host model, GEM-GDPS. The vertical resolution of GEM-GDPS was increased in 2006 as part of a technical update of the model at the Canadian Meteorological Centre (CMC). We perform a series of interconnecting 48-h simulations, where each simulation is initialised using observed meteorological analyses from CMC. Initial mercury concentrations for each 48-h simulation are provided by the previous simulation. Steady-state initial concentrations of mercury in non-seasonal snowpacks were generated for SORun and SRun by a 10-yr spin-up period starting from zero. All three simulations started with identical steady-state atmospheric mercury concentrations on 29 September 2004. To each of the three simulations an initial 3-month spin-up period was applied. The simulation period was from January, 2005 to December, 2009.

\section{Results and discussion}

\subsection{Snowpack-related mercury}

The verification of simulated snowpack-related mercury concentrations employs datasets that were compiled by Durnford and Dastoor (2011). These datasets are based on observations from numerous field studies performed in all areas of the globe. From the published reports of the field studies, Durnford and Dastoor (2011) calculated sample-size weighted means of the concentrations of mercury in surface snow, throughout the depth of the snowpack, and in snowpack meltwater. The reader is referred to Durnford and Dastoor (2011) for a detailed discussion on the calculation of the mean concentrations and on the contributing observations. The observed mean concentrations are based mainly on springtime observations and are provided by reports of field studies that date from 1975 to 2010 . Moreover, the observed concentration at a given location may be based on anywhere from a few to over a hundred published observations. Finally, "surface snow" is defined as anywhere from 1 to $15 \mathrm{~cm}$ by field studies and as $30 \mathrm{~cm}$ by the model.

Figure $2 \mathrm{a}$ and $\mathrm{b}$ present the five-year (2005-2009) average of SORun's simulated concentrations of mercury in the top snowpack layer and the top and bottom snowpack layers combined, respectively. Simulated data points characterized by at least a $2-\mathrm{cm}$ deep snowpack were included in the calculation. The simulated and observed concentrations are not expected to match perfectly as too many differences exist between the datasets. Mean and maximum observed values are represented in Fig. 2 as colored circles and squares, respectively.

In both the top layer of the snowpack (Fig. 2a) and in the top and bottom layers combined (Fig. 2b), the simulated concentration of total mercury exceeds $10 \mathrm{ng} \mathrm{L}^{-1}$ over sea ice around the edges of the Arctic Ocean, in the Canadian Archipelago, between Canada and Greenland, and in Hudson Bay. Simulated concentrations surpass $20 \mathrm{ng} \mathrm{L}^{-1}$ north of Siberia and Alaska, between the Canadian Archipelago and Greenland, and over Hudson Bay. Observations support these significant concentrations. With the exception of two observed concentrations of mercury in snowpacks (46 and $494 \mathrm{ng} \mathrm{L}^{-1}$ ), which are at inland locations in Greenland where AMDEs are not expected to have any influence and which are of questionable validity (Jackson, 1997), both simulated and observed concentrations of total mercury are less than $10 \mathrm{ng} \mathrm{L}^{-1}$ in snowpacks over Greenland and onshore in the Canadian Archipelago. In contrast, the simulated $\left(\sim 7 \mathrm{ng} \mathrm{L}^{-1}\right)$ and observed $\left(44.5 \mathrm{ng} \mathrm{L}^{-1}\right)$ concentrations of mercury in surface snow at Ny-Ålesund (to the east of northern Greenland at the edge of the plotted simulated concentrations) disagree. However, of the 17 field studies contributing to the observed concentration plotted at Ny-Ålesund, only 2 studies occurred outside of spring (Durnford and Dastoor, 2011); the observed concentration is typical of the AMDE 

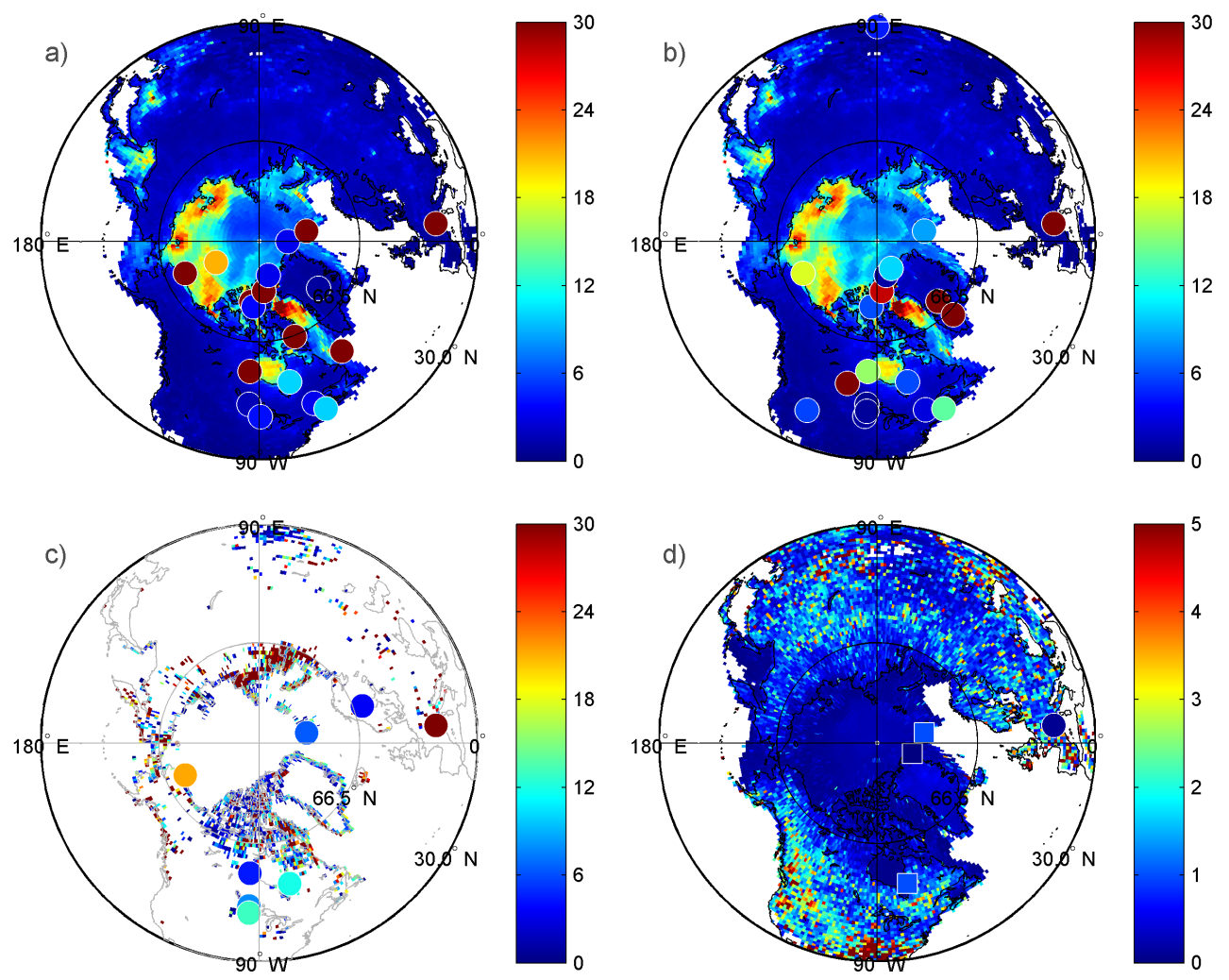

Fig. 2. Plotted, as simulated by SORun are: (a) the 5 -year average (2005 to 2009 ) concentration (ng L ${ }^{-1}$ ) of total mercury in the top snowpack layer, and (b) in the top and bottom snowpack layers combined; (c) the 5-yr average of each year's maximum monthly concentration (ng $\mathrm{L}^{-1}$ ) of total mercury in snowpack meltwater runoff; and d) the 5-yr average of the fraction (\%) of total mercury in the top and bottom snowpack layers combined that is GEM. Colored circles and squares represent mean and maximum observed values, respectively.

season, which is characterized by important mercury deposition (Lu et al., 2001; Berg et al., 2003; Ariya et al., 2004; Christensen et al., 2004; Heidam et al., 2004; Skov et al., 2004; Ferrari et al., 2005; Travnikov, 2005; Brooks et al., 2006; Kirk et al., 2006; Constant et al., 2007; Sommar et al., 2007; Johnson et al., 2008; Steffen et al., 2008). Since, during April/May, the average simulated concentration of mercury in surface snow is only $9 \mathrm{ng} \mathrm{L}^{-1}$ at $\mathrm{Ny}$-Ålesund but rises to $50 \mathrm{ng} \mathrm{L}^{-1}$ within $150 \mathrm{~km}$ to the north, a finer horizontal resolution may be required to reproduce the observed elevated springtime mercury concentration in surface snow at Ny-Ålesund itself. Interestingly, the agreement between the observed $\left(8.5 \mathrm{ng} \mathrm{L}^{-1}\right)$ and annually-averaged simulated $\left(\sim 8 \mathrm{ng} \mathrm{L}^{-1}\right)$ concentrations of mercury over the entire depth of the snowpack at Ny-Ålesund is extremely close.

At lower latitudes, the majority of the observed concentrations of mercury in both surface snow and throughout the snowpack's depth are less than $10 \mathrm{ng} \mathrm{L}^{-1}$ (Fig. 2). Although the observed $\left(4.5 \mathrm{ng} \mathrm{L}^{-1}\right)$ and simulated $\left(\sim 3 \mathrm{ng} \mathrm{L}^{-1}\right)$ concentrations of mercury throughout the snowpack's depth agree closely in the Himalayas, simulated concentrations tend to agree with the lowest observations in North America; the model may not be capturing all local environmen- tal effects. In midwestern Canada, SORun fails to reproduce the high observed concentration of mercury in snowpacks ( $520 \mathrm{ng} \mathrm{L}^{-1}$ ) that is associated with the Flin Flon smelting facility. It is likely that a much higher model horizontal resolution $(\sim 5 \mathrm{~km})$ is required to reproduce the extremely high observed concentration. Indeed, gross deposition simulated by GRAHM increased at Flin Flon from 26 to $293 \mu \mathrm{g} \mathrm{m}^{-2} \mathrm{yr}^{-1}$ with an increase in horizontal resolution from 1 to 0.15 degrees. Furthermore, the concentration of mercury in humus within $5 \mathrm{~km}$ of the smelter was measured at $100000 \mathrm{ppb}$ or 500-fold the regional background value (Henderson et al., 1998). The concentration of mercury in humus decreased with distance from the smelter, returning to the background value at a distance of $85 \mathrm{~km}$ (Henderson et al., 1998, McMartin et al., 1999). Given the site's significant contamination and given the fact that mercury can be transferred from the underlying soil and litter to the snowpack (Nelson et al., 2008), the entrainment of mercury from the underlying humus near Flin Flon into the snowpack may have augmented the snowpack's mercury content. Such entrainment is not represented in the snowpack model. In the Alps, the high observed means ( 68 and $131 \mathrm{~L}^{-1}$ for surface snow and throughout the snowpack, respectively) are based predominantly 
on springtime observations. Convection, which is active in spring and summer, lifts regional pollution (Maupetit et al., 1995; Cozic et al., 2008; Marusczak et al., 2011). Newly published results from Marusczak et al. (2011), which are not included in the plotted observed mean, provide a mean concentration of total mercury in Alpine surface snow during the first four months of 2009 of $\sim 3.5 \mathrm{ng} \mathrm{L}^{-1}$, which agrees well with this region's simulated concentration of mercury in both the top snowpack layer and the top and bottom layers combined $\left(\sim 2 \mathrm{ng} \mathrm{L}^{-1}\right)$. These authors observed concentrations of total mercury in surface snow above $6 \mathrm{ng} \mathrm{L}^{-1}$ only after mid April, with the greatest concentrations found after mid May. Unfortunately, at a 1-degree horizontal resolution, the snowpack simulated by GRAHM vanishes during March in this region.

An interesting feature of Fig. 2a and $b$ is the fact that GRAHM predicts the existence of a snowpack of at least $2 \mathrm{~cm}$ depth over terrestrial surfaces as far south as $30^{\circ} \mathrm{N}$ at least once during the five-year period. At these low latitudes, it is not expected that snowpacks outside of mountainous regions are long-lived. By definition, mercury deposited through wet processes contributes to the snowpack's mercury burden from the onset. Moreover, mercury deposited through wet processes is retained by snowpacks more strongly than mercury deposited through dry processes (Durnford et al., 2012); mercury deposited through wet processes appears to be more centrally located within snow grains than mercury deposited through dry processes (Seigneur et al., 1998; Douglas et al., 2008; Durnford et al., 2012). Consequently, for these short-lived snowpacks, even though the deposition of mercury through dry processes is continuous (Lin et al., 2006), the fraction of the snowpack's mercury burden that is contributed by wet deposition is probably significantly higher than that contributed by dry deposition.

Figure 2c presents the five-year (2005-2009) average of each year's greatest monthly average concentration of mercury in snowpack meltwater runoff as simulated by SORun. To be included in the calculation, the depth of the runoff must be at least $2 \mathrm{~cm}$. The representation of horizontal flow, which would permit the simulation of the accumulation of runoff in low-lying areas, is not currently included in the model. Consequently, to represent the assumption that, within 48 hours, the runoff is either absorbed by the underlying surface and/or enters a larger body of water, the depth of the runoff is reset to zero every 48 hours over soil and glaciers (Sect. 2.2). To represent the drainage of meltwater from ponds on sea and lake ice through cracks in the ice, meltwater is transferred in the model to the underlying body of water at a constant rate. The uneven distribution of data points in Fig. $2 \mathrm{c}$ indicates that the simulated runoff reaches a depth of $2 \mathrm{~cm}$ infrequently. The greater frequency of data points at higher latitudes suggests that the snowpack melts more rapidly at higher than mid latitudes; the day is longer during the snowmelt period at higher latitudes. Since no minimum depth applies to the observed concentration of mercury in runoff and since the observa- tions plotted in Fig. 2c represent the mean concentration in the snowpack meltwater's ionic pulse, which lasts for a few days (Bales et al., 1989, 1990; Bishop et al., 1995; Allan et al., 2001; Kuhn, 2001; Lindberg et al., 2002; Dommergue et al., 2003, 2010), we expect the simulated concentration to be as great as that observed if the simulated runoff depth reaches $2 \mathrm{~cm}$ during the ionic pulse. Otherwise, we expect the simulated concentration to be less than that observed.

In Fig. 2c, the simulated concentration of mercury in runoff tends to be below $10 \mathrm{ng} \mathrm{L}^{-1}$ in North America and above that in Europe and northern Siberia. It is difficult to compare the simulated and observed concentrations given how little the two datasets overlap. However, the simulated concentrations do appear to be consistent with the observations shown. Interestingly, the simulated concentrations also show good agreement with the concentrations of dissolved gaseous mercury shown in Andersson et al. (2008b).

The five-year average (2005-2009) of the fraction of total mercury that is GEM in the top and bottom snowpack layers combined, as simulated by SORun, is presented in Fig. 2 d. To date, only 4 observations of this fraction are available in the literature for the verification of the simulated fractions. Moreover, only one of the studies provides an actual value (Faïn et al., 2007). The remaining three studies simply specify that the fraction that is GEM is no greater than the value provided (Dommergue et al., 2003; Ferrari et al., 2004a, 2005). Thus, the guidance provided by the observations is somewhat limited.

In Fig. 2d, the simulated fractions of total mercury in the snowpack that is GEM show excellent agreement with the few available observed fractions. This indicates that the rates of net photoreduction and revolatilization are well balanced in the snowpack model. However, more observations are required to confirm or reject the distinctly latitudinal distribution to the simulated fractions, where the fractions are well below $1 \%$ in the Arctic but are $1 \%$ to $5 \%$ in midlatitudes.

\subsection{Atmospheric mercury}

During the development of the snowpack/meltwater model, GRAHM's simulated atmospheric surface-level GEM concentrations were compared to hourly observations at 18 stations around the Arctic and across Canada. In the interests of brevity, here we present verification for 3 sample stations at widely differing latitudes (Fig. 7a). The latitudinal variation is important as the snowpack model's sensitivity varies latitudinally (Sect. 2.2). Figure 3 presents concentrations of atmospheric surface-level GEM at Alert in the Canadian Arctic $\left(82.5^{\circ} \mathrm{N}, 62.3^{\circ} \mathrm{W}, 210 \mathrm{~m}\right.$ a. s. 1 .), Kuujjuarapik on subarctic Hudson Bay, Canada (55. $3^{\circ} \mathrm{N}, 77.7^{\circ} \mathrm{W}, 14 \mathrm{~m}$ a.s.l.) and Point Petre in mid-latitude Canada $\left(43.8^{\circ} \mathrm{N}, 77.2^{\circ} \mathrm{W}\right.$, $77 \mathrm{~m}$ a.s.1.). The longitudes and elevations of the three stations are similar. Alert and Kuujjuarapik are remote from anthropogenic sources of mercury but experience long-range transport events (Poissant and Pilote, 2003; Steffen et al., 

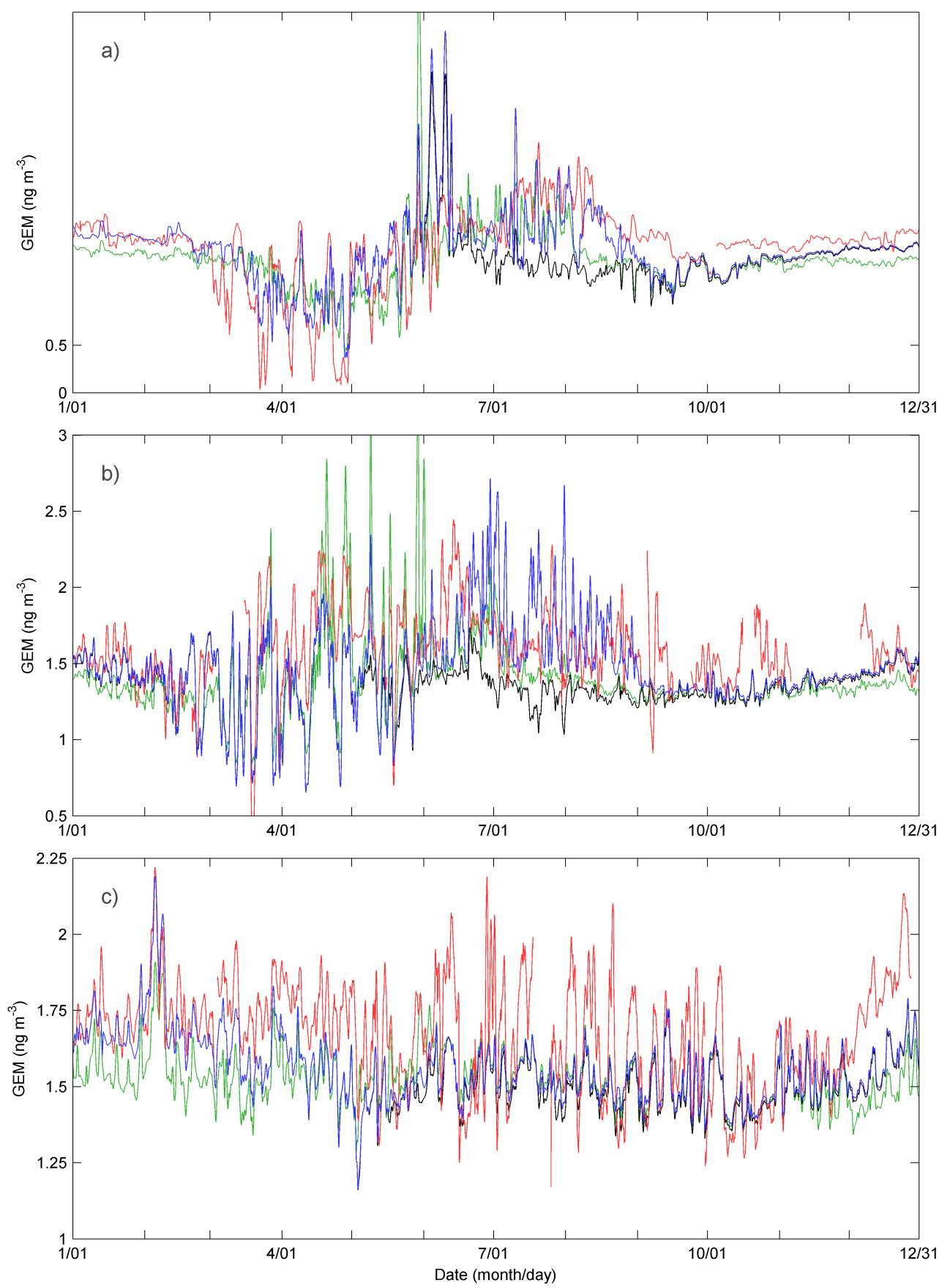

Fig. 3. Presented are time series of concentrations $\left(\mathrm{ng} \mathrm{m}^{-3}\right.$ ) of surface-level atmospheric GEM at (a) Alert in 2005, (a) Kuujjuarapik in 2007, and (c) Point Petre in 2005 as observed (red) and as simulated by BRun (green), SORun (blue) and SRun (black).

2005; Durnford et al., 2010). Point Petre is a rural site that is affected by regional pollution episodically (Blanchard et al., 2002; Kellerhals et al., 2003; Temme et al., 2007; Wen et al., 2011). Thus, although the latitudinal difference is not the only difference between these three stations, it is likely the most important difference. The plotted concentrations at these three locations (Fig. 3) have been smoothed in order to eliminate noise following Durnford et al. (2010): a 24-h run- ning mean is applied to the observed concentrations, while a 12-h running mean is applied to the simulated concentrations. The observations are smoothed more since they are point values, whereas the simulated concentrations represent an area of up to $\sim 100 \mathrm{~km}$ by $\sim 100 \mathrm{~km}$ and, thus, are already smoothed spatially.

At Alert, SORun reproduces the observed wintertime background atmospheric GEM concentrations better than the 
base run, BRun (Fig. 3a). Mercury concentrations simulated by SRun are overwritten by those of SORun at the start and end of the year in all three panels of Fig. 3 as SRun and SORun differ only in their summertime oceanic emissions from Hudson Bay and north of $66.5^{\circ} \mathrm{N}$ (Sect. 2.3). In spring, the simulation by SORun of the revolatilization at Alert of AMDE-associated deposition is far more accurate than that by BRun

At the onset of snowmelt in June at Alert, both SORun and BRun generate overly large spikes of GEM (Fig. 3a). However, atmospheric GEM concentrations that are considerably higher than the hemispheric background and that are known as Atmospheric Mercury Emission Events (AMEEs) (Cole and Steffen, 2010) are observed at high-latitudes at the onset of snowmelt (Dommergue et al., 2003; Faïn et al., 2007; Sommar et al., 2007; Brooks et al., 2008b; Douglas et al., 2008). It has been hypothesized that these spikes are generated by an increased rate of mercury reduction within the snowpack (Dommergue et al., 2003). It is suggested that reactions are faster in the quasi-liquid medium that surrounds individual snow grains so that, when this layer thickens during snowmelt, the reaction site expands and the overall rate of reaction increases (Durnford and Dastoor, 2011). In the snowpack model's representation of net photoreduction within the snowpack (Eq. (5)), $\mathrm{k}_{\mathrm{NP}}$, the base rate of net photoreduction, is held fixed at all times while the value of $\mathrm{C}_{\mathrm{ins}}$, the coefficient representing the availability of solar radiation, increases with the solar zenith angle (Eq. (6)). This suggests strongly that the spikes in high-latitude atmospheric GEM concentration observed at the onset of snowmelt are related purely to the increased availability of solar radiation. The thickening of the quasi-liquid layer itself does not seem to increase the rate of net photoreduction. This supports our assumption that the molecules of oxidized mercury occupy no more than a monolayer on the outer surface of snow grains (Sect. 2.2).

SORun's overly large simulated spikes in atmospheric GEM concentration at the onset of snowmelt at Alert (Fig. 3a) may indicate that the calculation of the snowpack's net photoreduction (Eq. (5)) needs further refinement. For instance, the partitioning of the snowpack's content of oxidized mercury into fractions that are and are not available for reduction according to the halide content of the snowpack may be required. On the other hand, the fact that the overly large concentration spikes of Fig. 3a coincide with the onset of snowmelt may indicate that it is the snowpack model's processing of melting snowpacks that is most relevant to the overprediction of these spikes. Currently, following the present state of knowledge, all GEM in the melted portion of the snowpack is emitted to the atmosphere (Sect. 2.2). It is possible that a fraction of this GEM should actually be transferred to the snowpack meltwater.

From mid-June through the end of August, SRun, which uses the snowpack/meltwater model and no oceanic mercury emissions from the Arctic Ocean or Hudson Bay from May through August (Sect. 2.3), is unable to reproduce the observed summertime maximum in atmospheric GEM concentrations at Alert (Fig. 3a). The origin of this maximum is not yet known; it is simply known that air masses passing at low altitudes over the central Arctic tend to be characterized by higher concentrations of GEM (Hirdman et al., 2009). Figure 3 demonstrates that the revolatilization of mercury from snowpacks and runoff is responsible only for the surge in emissions at the onset of snowmelt. The significant difference between concentrations simulated by SORun and SRun strongly suggests that the observed summertime maximum is caused by mercury emitted from the Arctic Ocean itself. The maximum in SORun is supported by elevated emissions from the open ocean (Hirdman et al., 2009). In reality, evasion in the Canadian Arctic Archipelago may also provide support; concentrations of mercury in both runoff (Fig. 2c) and surface waters (Kirk et al., 2008; Andersson et al., 2008b) are elevated locally in the Archipelago. Concerning the shapes of the observed and simulated time series, it is highly likely that the volatility of the summertime GEM concentrations is driven by oceanic emissions; onshore and offshore winds almost definitely coincide with maxima and minima, respectively, in the observed time series. It is probable that the extremely high concentrations of marine mercury that have been observed in wholly or partially ice-covered regions of arctic waters and Hudson Bay in April and May (Kirk et al., 2006; Sommar et al., 2007; St. Louis et al., 2007) and July through September (Andersson et al., 2008b) gain access to the atmosphere through cracks in the sea ice (Kirk et al., 2006; St. Louis et al., 2007). The end of the summertime maximum coincides with the arrival of colder atmospheric temperatures. Colder temperatures promote the formation of sea ice; gaps in the sea ice close. They also reduce the emission of marine mercury through the temperature dependence of the Henry's law constant for GEM (Poissant et al., 2000; Andersson et al., 2008a). The relative importance of snowpack and oceanic emissions in the Arctic will be discussed further in Sect. 3.3.3.

At Kuujjuarapik, SORun is again able to reproduce the observed wintertime background atmospheric GEM concentrations more accurately than BRun (Fig. 3b). Furthermore, the timing by SORun of the springtime peaks and troughs is excellent at Kuujjuarapik. Thus, the snowpack/meltwater model is seen to perform well at this site. During summer, the difference between the concentrations simulated by SORun and SRun suggests that oceanic mercury emissions are important at Kuujjuarapik, in terms of their contribution both to the mean GEM concentration and its variability.

At Point Petre, the wintertime atmospheric GEM concentrations simulated by SORun are noticeably closer to the observations than those of BRun (Fig. 3c); the seasonality of the simulated atmospheric GEM concentrations improves significantly. Experiments with atmospheric chemical transformations were unable to produce the same degree of seasonality. Interestingly, while the difference between SORun and SRun 

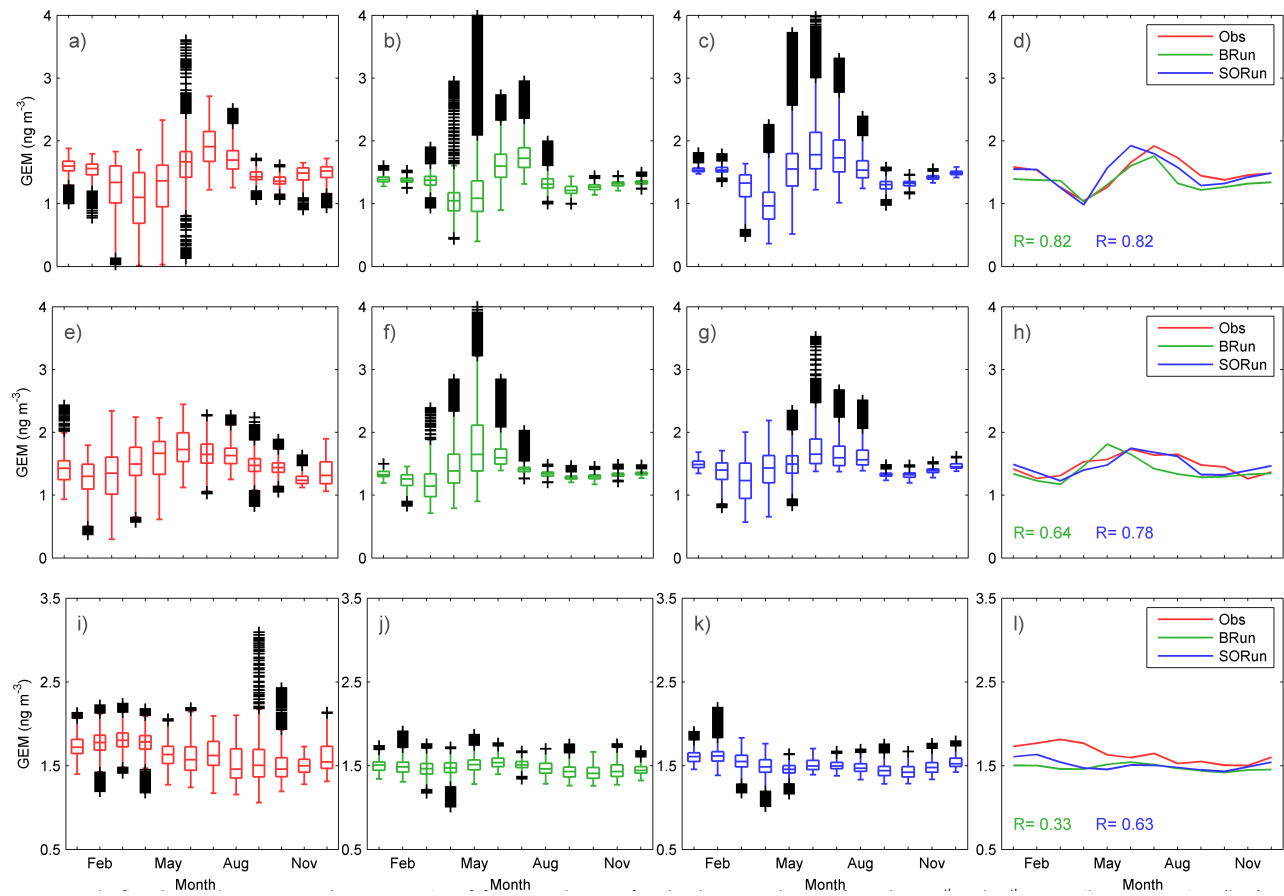

Fig. 4. The first three columns present boxes consisting of, for atmospheric surface-level GEM, each month's median, 25th and 75th percentile concentrations (box's centre line and boundaries). The whiskers represent the mean \pm 2.7 standard deviations, enclosing $\sim 99 \%$ of data points in a normally distributed dataset. Outliers are plotted using "+". The first column (a, e, i) presents statistics based on observed concentrations. The second column (b, f, j) presents statistics based on BRun. The third column $(\mathbf{c}, \mathbf{g}, \mathbf{k})$ presents statistics based on SORun. The fourth column provides monthly mean concentrations and correlation coefficients between the observed and simulated monthly means, following the color-coding of the legend. The first row (a-d) presents statistics for Alert, based on $5 \mathrm{yr}$ (2005-2009) of concentrations. The second row (e-h) presents statistics for Kuujjuarapik, based on 3 yr (2007-2009) of concentrations. The third row (i-l) presents statistics for Point Petre, based on 3 yr (2005-2007) of concentrations.

extends only through September/October at Alert and Kuujjuarapik, this difference extends right through December at Point Peter; although the lack or presence of high-latitude summertime oceanic mercury emissions affects atmospheric GEM concentrations more strongly at high latitudes during summer, the impact of these emissions is felt for longer at midlatitudes.

Figure 4 provides an objective analysis of the ability of BRun and SORun to reproduce observed concentrations of atmospheric GEM over multiple years. At Alert, both the shape of SORun's distribution of monthly medians and the degree of variability are more accurate than BRun's (Fig. 4ac). SORun also does an excellent job of reproducing the observed distribution of monthly means at Alert (Fig. 4d), apart from a slight forwards shift of the summertime peak. It is possible that transferring a fraction of the GEM contained in the melted portion of the snowpack to the snowmelt instead of releasing it immediately to the atmosphere, as discussed above, would delay the emission of GEM somewhat and reduce the forwards shift of the maximum monthly mean concentration. Nonetheless, despite this forwards shift, the correlation coefficient between the distribution of monthly means as observed and as simulated by SORun matches BRun's excellent coefficient of 0.82; SORun's wintertime monthly mean atmospheric GEM concentrations agree more closely with the observed means than those of BRun.

At Kuujjuarapik, SORun reproduces the distribution of the monthly median concentrations more accurately than does BRun (Fig. 4e-g). The unfortunate drop in SORun's median mercury concentration in September, along with that month's decline in variability, suggests that important oceanic mercury emissions from Hudson Bay continue past the end of August; they were provided in SORun only until the end of August. Nonetheless, the overall degree of variability in SORun agrees most closely with the observed variability. Furthermore, the correlation coefficient between the simulated and observed distributions of monthly means (Fig. 4h) is distinctly higher for SORun (0.78) than for BRun (0.64).

At Point Petre, the seasonal cycle in the distributions of both the monthly median (Fig. 4i-k) and mean (Fig. 4l) concentrations of atmospheric GEM as simulated by SORun agrees more closely with the observed cycle than as simulated by BRun. This improvement in the seasonal cycle by SORun causes the correlation coefficient between the monthly distribution of mean GEM concentrations as observed and as simulated by SORun to jump to 0.63 from 

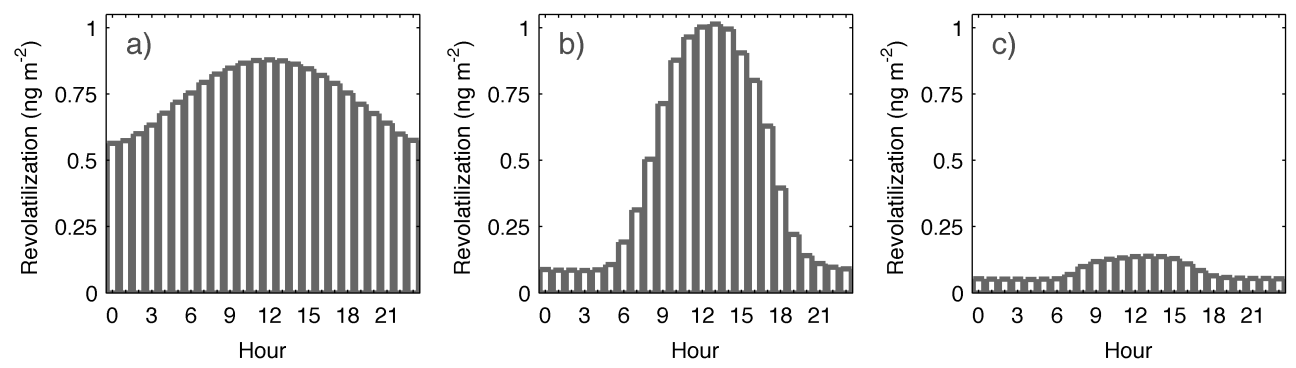

Fig. 5. Shown is the 5-yr (2005-2009) average from SORun of revolatilization of GEM from snowpacks as a function of the local hour at (a) Alert, (b) Kuujjuarapik and (c) Point Petre.

BRun's coefficient of 0.33 . Both SORun and BRun fail to capture the full extent of the observed variability as represented by the distributions of the 25th and 75th concentrations and the outliers, particularly in summer and fall. This suggests that soil/atmosphere fluxes, which are not dynamically represented in GRAHM, have an important effect on atmospheric mercury concentrations.

\subsection{Deposition and emission}

For the sake of clarity, we commence the discussion on deposition and emission by defining the yearly net deposition and yearly accumulation at the surface as these terms are used in Sect. 3.3.3.

\subsubsection{Yearly net deposition}

We define the yearly net deposition as the amount of new mercury that is added to the surface within the same year. It is calculated as the total yearly gross deposition minus the portion of that deposition that is revolatilized the same year. This will include rapid revolatilization from snowpacks, snowpack meltwater runoff, soils, vegetation and bodies of water. At this point, we do not have knowledge of the rapid revolatilization of mercury from soils, vegetation and bodies of water from the model. Thus, our current estimate of yearly net deposition is calculated by removing mercury revolatilization from snowpacks and snowpack meltwater runoff from total yearly gross deposition and therefore it represents an upper limit.

\subsubsection{Yearly accumulation at the surface}

We define the yearly accumulation at the surface as how much mercury is accumulated on the Earth's surface in a given year. It explains the change in mercury concentration at the surface as a result of exchanges with the atmosphere. It is calculated as the total yearly gross deposition minus total surface non-anthropogenic emissions for that year. Anthropogenic emissions are excluded since they represent the mobilization of mercury from under the surface to the surface; no mercury is removed from the surface. Thus, included in the yearly accumulation at the surface but not in the yearly net deposition is the re-emission of mercury that was deposited prior to the current year. Environmental compartments containing such legacy pools of deposited mercury include soils, bodies of water, multiyear snowpacks, glaciers and permafrost. GRAHM currently represents the emission of legacy pools of mercury from soils and bodies of water.

\subsubsection{Results}

The five-year average (2005-2009) of the revolatilization of mercury deposited onto snowpacks as a function of the local hour, as simulated by SORun at Alert, Kuujjuarapik and Point Petre, is presented in Fig. 5. The simulated revolatilization at all three locations peaks near or just after local noon, agreeing with observations (Steffen et al., 2002; Ferrari et al., 2005, 2008; Brooks et al., 2006; Faïn et al., 2007; Sommar et al., 2007; Johnson et al., 2008). Interestingly, the shapes of the three distributions are quite different. The distinct increase of revolatilization with latitude suggests that the greater deposition associated with high-latitude AMDEs tends to be followed by greater revolatilization. The fact that the average amount of mercury revolatilized per hour at midday is greatest at Kuujjuarapik likely reflects the fact that the site's significant AMDE-associated deposition is revolatilized during days that are less than $24 \mathrm{~h}$ long. In contrast, at Alert, which experiences 24-h daylight, the revolatilization of AMDE-associated deposition is continuous. In consequence, less mercury is emitted per hour on average at midday and the midday emission peak is less pronounced.

The horizontal seasonal distributions of gross deposition, the revolatilization of deposited mercury from snowpacks and runoff, and net deposition of mercury, as simulated by SORun and averaged over 2005 to 2009, are presented in Fig. 6. Each season extends over three months with winter defined as December/January/February. Midlatitude wet mercury deposition, as simulated by SORun, was found to verify against Mercury Deposition Network data from the National Atmospheric Deposition Network (Prestbo and Gay, 2009) better than that simulated by BRun in Canada and the northern US (not shown). Performance was comparable in the southern US. In midlatitudes, gross deposition 
Table 1. Deposition and emission for the area polewards of $66.5^{\circ} \mathrm{N}$.

\begin{tabular}{llllllll}
\hline Season & $\begin{array}{l}\text { Emission: } \\
\text { snowpack }(\mathrm{Mg})\end{array}$ & $\begin{array}{l}\text { Emission: } \\
\text { runoff }(\mathrm{Mg})\end{array}$ & $\begin{array}{l}\text { Emission: } \\
\text { oceanic }(\mathrm{Mg})\end{array}$ & $\begin{array}{l}\text { Other } \\
\text { emission }(\mathrm{Mg})\end{array}$ & $\begin{array}{l}\text { Gross } \\
\text { deposition }(\mathrm{Mg})\end{array}$ & $\begin{array}{l}\text { Net } \\
\text { deposition }(\mathrm{Mg})\end{array}$ & $\begin{array}{l}\text { Net } \\
\text { accumulation }(\mathrm{Mg})\end{array}$ \\
\hline winter & 12 & 0 & 3 & 0 & 29 & 17 & 13 \\
spring & 142 & 0 & 4 & 1 & 205 & 63 & 58 \\
summer & 35 & 1 & 22 & 2 & 78 & 43 & 19 \\
fall & 8 & 0 & 4 & 0 & 38 & 30 & 27 \\
year & 197 & 1 & 33 & 3 & 350 & 153 & 117 \\
\hline
\end{tabular}
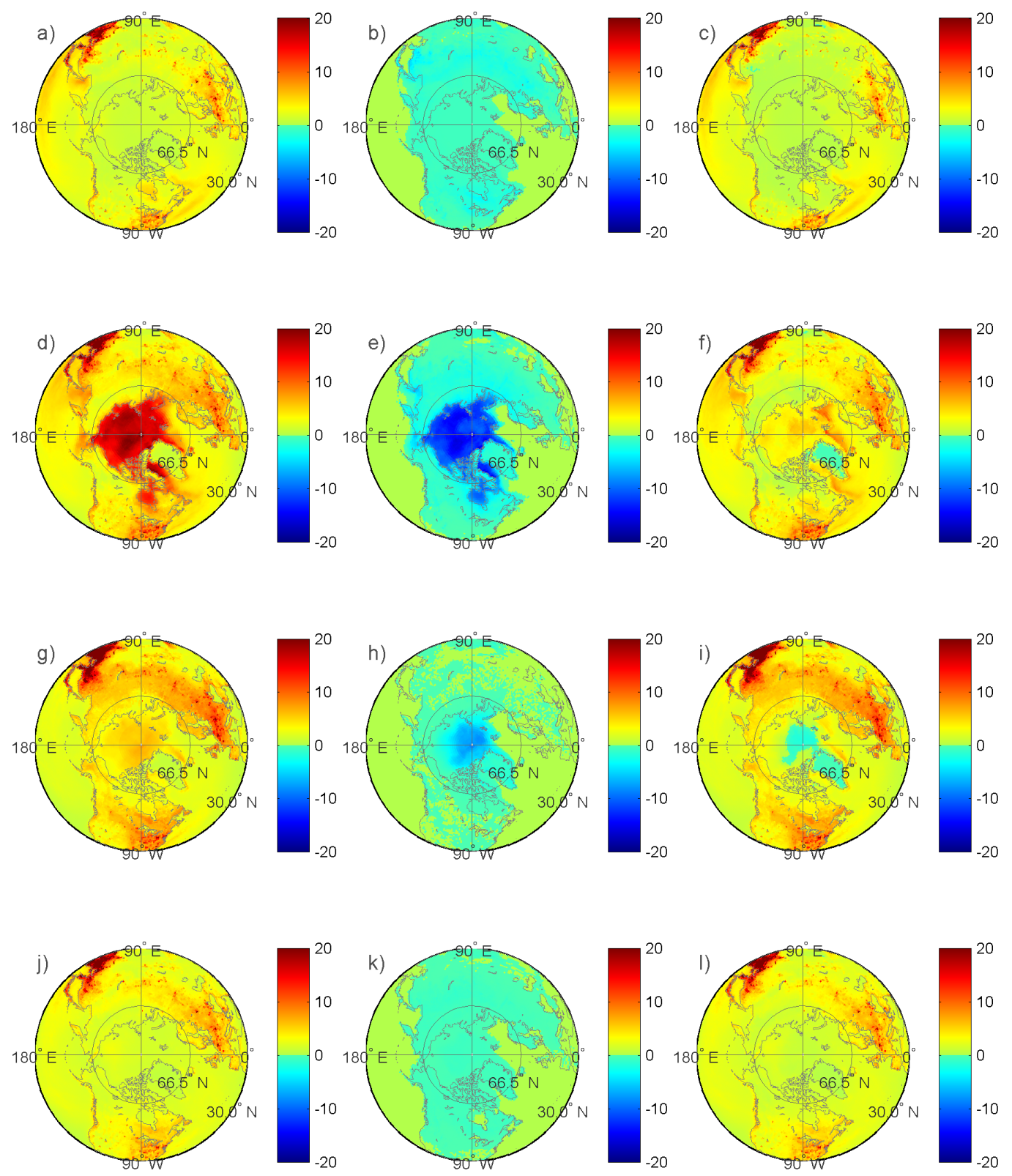

Fig. 6. From left to right by column are, in $\mu \mathrm{g} \mathrm{m}{ }^{-2}$, gross deposition (a, $\left.\mathbf{d}, \mathbf{g}, \mathbf{j}\right)$, the revolatilization from snowpacks and runoff (b, e, h, $\left.\mathbf{k}\right)$, and net deposition (c, f, i, l) based on 5 yr (2005-2009) of seasonal data from SORun. The first row (a-c) presents data for winter (December through February), followed by spring (d-f), summer (g-i), and fall $(\mathbf{j}-\mathbf{l})$. 

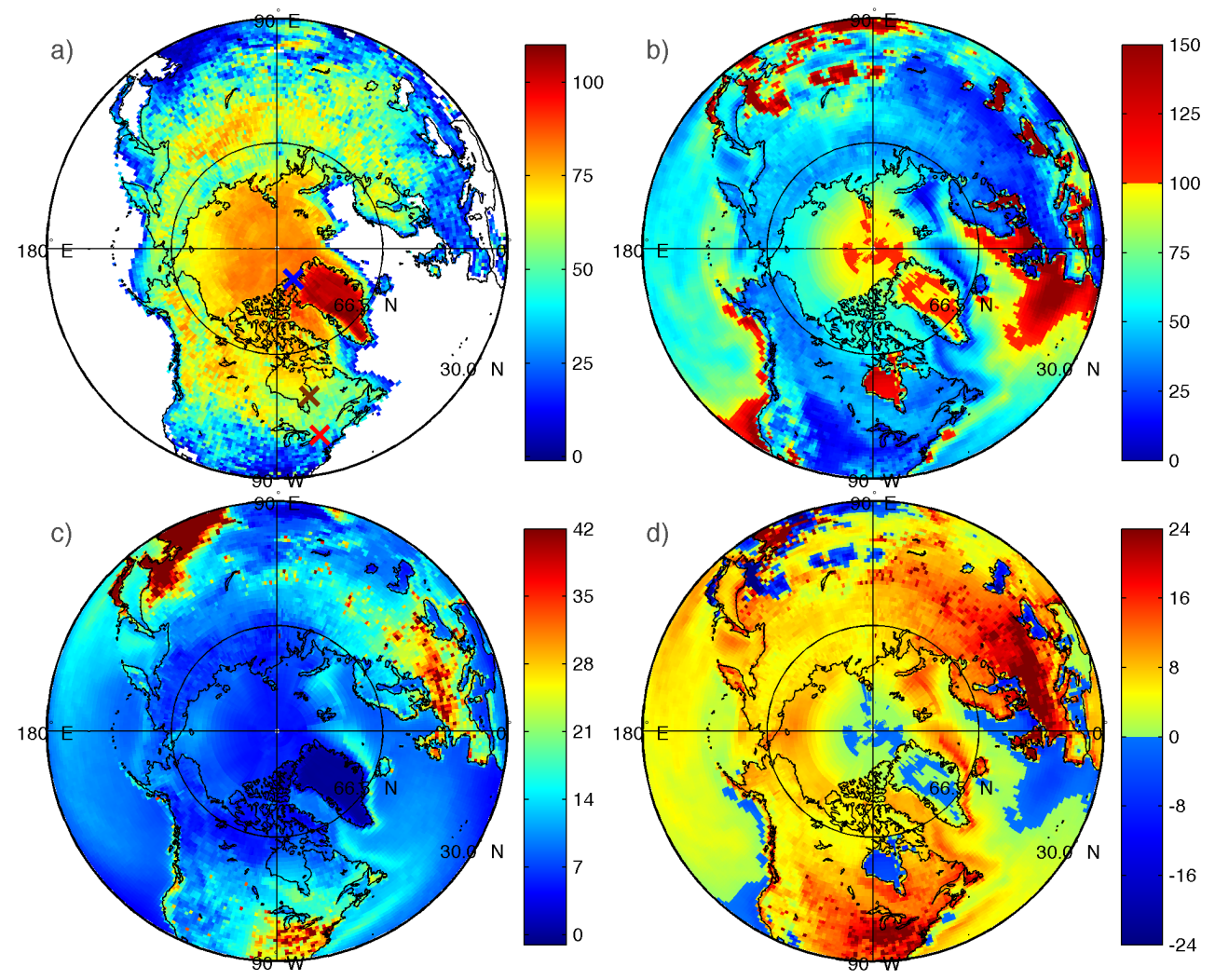

Fig. 7. Presented are annual averages based on $5 \mathrm{yr}$ (2005-2009) of data from SORun of (a) the fraction (\%) of mercury deposited onto snowpacks that is revolatilized. The blue, brown and red crosses indicate the location of Alert, Kuujjuarapik and Point Petre, respectively; (b) total mercury emission from the surface as a fraction (\%) of gross mercury deposition; (c) net mercury deposition ( $\left.\mu \mathrm{g} \mathrm{m} \mathrm{m}^{-2} \mathrm{yr}^{-1}\right)$; and (d) net mercury accumulation $\left(\mu \mathrm{g} \mathrm{m}^{-2} \mathrm{yr}^{-1}\right)$.

is greatest in summer and spring whereas net deposition is greatest in summer, followed by spring, as a result of the springtime revolatilization of mercury deposited onto snowpacks (Fig. 6). The impact of snowpacks on midlatitude net deposition will be discussed further below.

In the Arctic, as a result of AMDEs, we estimate that gross deposition is 2.6-fold greater in spring than in summer, which is, in turn, 2.0-fold greater than in fall (Table 1). Despite significant revolatilization of mercury deposited onto snowpacks, springtime net deposition is important everywhere in the Arctic except Greenland (Fig. 6), amounting to an estimated $63 \mathrm{Mg}$ north of $66.5^{\circ} \mathrm{N}$. This represents $41 \%$ of the region's yearly net deposition. During fall, net deposition in the Arctic is half that during spring. In winter, net deposition is minimal. During summer, the Arctic as a whole experiences net deposition $\left(43 \mathrm{Mg}\right.$ north of $\left.66.5^{\circ} \mathrm{N}\right)$. However, despite greater summertime gross deposition in the High than Low Arctic, we estimate that the High Arctic experiences a negative net deposition during summer, as does Greenland, as a result of the strong revolatilization of mercury deposited onto snowpacks during both summer and the previous seasons. Indeed, we estimate that, even in summer, when oceanic emissions north of $66.5^{\circ} \mathrm{N}$ are at their greatest $(22 \mathrm{Mg}$; Ta- ble 1), revolatilization from snowpacks and runoff is 1.6-fold stronger than evasion from oceans.

Also of interest is the seasonal distribution of net deposition and net accumulation (Fig. 6, Table 2) for the Hudson Bay System, which consists of Hudson Bay, Foxe Basin and Hudson Strait (Hare et al., 2008). We estimate that the yearly net deposition for this region is $14 \mathrm{Mg}$, with the net deposition distributed evenly between the seasons. The measurement-based estimate from Kirk et al. (2006) of a net deposition to Hudson Bay alone of $0.26 \pm 0.20 \mathrm{Mg}$ from the entire snowpack season is lower than our estimate for the entire Hudson Bay System of $\sim 8 \mathrm{Mg}$ for the same period. The heterogeneity of both AMDE-associated mercury deposition (Ferrari et al., 2005; Kirk et al., 2006; Steffen et al., 2008) and the fraction of mercury deposited onto snowpacks that is revolatilized (Fig. 7a) could explain this discrepancy. We further estimate that the region experiences a yearly net accumulation at the surface of $1 \mathrm{Mg}$; the revolatilization of mercury from snowpacks (14 $\mathrm{Mg} \mathrm{yr}^{-1}$, with $12 \mathrm{Mg}$ in spring) and oceanic evasion ( $13 \mathrm{Mg} \mathrm{yr}^{-1}$, with $11 \mathrm{Mg}$ in summer) balance gross atmospheric deposition $\left(28 \mathrm{Mg} \mathrm{yr}^{-1}\right)$ almost perfectly on an annual basis. Similarly, Hare et al. (2008) estimated a yearly net accumulation at the surface in the 
Table 2. Deposition and emission for the Hudson Bay System.

\begin{tabular}{llllllll}
\hline Season & $\begin{array}{l}\text { Emission: } \\
\text { snowpack }(\mathrm{Mg})\end{array}$ & $\begin{array}{l}\text { Emission: } \\
\text { runoff }(\mathrm{Mg})\end{array}$ & $\begin{array}{l}\text { Emission: } \\
\text { oceanic }(\mathrm{Mg})\end{array}$ & $\begin{array}{l}\text { Other } \\
\text { emission }(\mathrm{Mg})\end{array}$ & $\begin{array}{l}\text { Gross } \\
\text { deposition }(\mathrm{Mg})\end{array}$ & $\begin{array}{l}\text { Net } \\
\text { deposition }(\mathrm{Mg})\end{array}$ & $\begin{array}{l}\text { Net } \\
\text { accumulation }(\mathrm{Mg})\end{array}$ \\
\hline winter & 2 & 0 & 0 & 0 & 5 & 3 & 3 \\
spring & 12 & 0 & 2 & 0 & 15 & 3 & 1 \\
summer & 0 & 0 & 11 & 0 & 5 & 5 & -6 \\
fall & 0 & 0 & 0 & 0 & 3 & 3 & 3 \\
year & 14 & 0 & 13 & 0 & 28 & 14 & 1 \\
\hline
\end{tabular}

Hudson Bay System of $1.5 \mathrm{Mg}$. These authors estimated that rivers provide $1.9 \mathrm{Mg} \mathrm{yr}^{-1}$ to the system. The importance of the riverine source for this system is supported by Fig. 6, which suggests significant net deposition to the extensive (over $3.7 \times 10^{6} \mathrm{~km}^{2}$ ) watershed of this system. During summer, we estimate that the strong oceanic evasion generates a net accumulation of $-6 \mathrm{Mg}$ in the Hudson Bay System. In Sect. 3.2, summertime oceanic emissions were found to contribute significantly to atmospheric GEM concentrations at Kuujjuarapik. Although Strode et al. (2007) also found net evasion over Hudson Bay in July, Soerensen et al. (2010) estimated net accumulation in Hudson Bay during summer. Both studies used the GEOS-Chem model.

Figure 7a presents the horizontal distribution, as simulated by SORun, of the 5-yr (2005-2009) average of the fraction (\%) of mercury deposited onto snowpacks that is revolatilized. Not surprisingly, given the much longer lifetime of snowpacks versus runoff, the annually averaged revolatilization of mercury from runoff is insignificant compared to that of snowpacks (e.g., Tables 1,2). Therefore, Fig. 7a will be discussed in terms of revolatilization from snowpacks alone. The fraction revolatilized is greatest over Greenland $(\sim 100 \%)$, possibly as a consequence of the region's low deposition (Fig. 6). Fractions greater than $100 \%$ indicate that mercury deposited during the previous year(s) is being revolatilized. Over the Arctic Ocean, the fraction is $\sim 70 \%$ to $80 \%$, which suggests efficient snowpack ventilation forced by windy conditions over the relatively flat terrain. The fractions are likely higher in the central Arctic Ocean than around its edges as a result of the greater saltiness of snowpacks over first-year than multi-year sea ice. As mentioned in Sect. 2.2, halogen species both oxidize and stabilize mercury within the snowpack, promoting its retention. The lesser fractions in the area of Siberia and Alaska north of $66.5^{\circ} \mathrm{N}(\sim 65 \%)$ suggest less efficient snowpack ventilation; wind speeds are likely reduced through friction with the rougher terrain. The variability of the fractions between 45 and $65^{\circ} \mathrm{N}(\sim 50 \%$ to $80 \%)$ is likely produced by varying amounts of snowpack ventilation related to terrain differences, varying degrees of mercury burial caused by a range of snowpack depths, and the varying retention of snowpack mercury by different canopy types. The smallest revolatilization fractions, which are found mainly south of $45^{\circ} \mathrm{N}(\sim 10 \%$ to $50 \%)$, may be produced by snowfalls melt- ing so rapidly that their mercury content is transferred to the underlying surface or a nearby body of water before significant revolatilization can occur from either the snowpack or its meltwater runoff.

Considering the impact of snowpacks on mercury deposition within four northern hemispheric latitude bands (30 to $45^{\circ} \mathrm{N}, 45$ to $60^{\circ} \mathrm{N}, 60$ to $65^{\circ} \mathrm{N}, 65$ to $90^{\circ} \mathrm{N}$ ) using five years (2005-2009) of output from SORun, we estimate that, on an annual basis, the fraction of gross deposition that is received by snowpacks increases continuously with increasing latitude band from an average of $6 \%$ ( 30 to $45^{\circ} \mathrm{N}$ ) to $20 \%$ (45 to $60^{\circ} \mathrm{N}$ ) to $41 \%\left(60\right.$ to $65^{\circ} \mathrm{N}$ ) to $75 \%$ (polewards of $66.5^{\circ} \mathrm{N}$; Table 3). As suggested by Fig. 7a, the average fraction of mercury deposited onto snowpacks that is revolatilized annually also increases continuously with latitude band from $39 \%$ $\left(30\right.$ to $\left.45^{\circ} \mathrm{N}\right)$ to $57 \%\left(45\right.$ to $\left.60^{\circ} \mathrm{N}\right)$ to $67 \%\left(60\right.$ to $\left.66.5^{\circ} \mathrm{N}\right)$ to $75 \%$ (polewards of $66.5^{\circ} \mathrm{N}$ ). Consequently, yearly net deposition is $98 \%$ of gross deposition from 30 to $45^{\circ} \mathrm{N}, 89 \%$ of gross deposition from 45 to $60^{\circ} \mathrm{N}, 73 \%$ of gross deposition from 60 to $66.5^{\circ} \mathrm{N}$, but only $44 \%$ of gross deposition within the Arctic Circle. During spring, the latitudinal gradients of both the fraction of gross deposition that is received by snowpacks and the fraction of mercury deposited onto snowpacks that is revolatilized tend to be stronger than on an annual basis. Therefore, while net deposition as a fraction of gross deposition is still, on average, $98 \%$ from 30 to $45^{\circ} \mathrm{N}$, it decreases to $83 \%$ from 45 to $60^{\circ} \mathrm{N}, 52 \%$ from 60 to $66.5^{\circ} \mathrm{N}$ and $31 \%$ polewards of $66.5^{\circ} \mathrm{N}$ during spring. In the Hudson Bay System, net deposition as a fraction of gross deposition is estimated to be $51 \%$ on an annual basis and $27 \%$ during spring. Thus, according to the dynamic snowpack/meltwater model, snowpacks provide the surface with a fairly effective barrier against atmospheric mercury, with the efficacy increasing with latitude. Stocker et al. (2007), using a box model, found that snowpacks also transfer semivolatile organic compounds to the underlying surface more at lower than at high latitudes.

As mentioned above, we estimate, using the dynamic snowpack model, that $75 \%$ of mercury deposited onto snowpacks polewards of $66.5^{\circ} \mathrm{N}$ is revolatilized annually (Table 3). Dastoor et al. (2008) and Holmes et al. (2010) provided estimates of $59 \%$ and $60 \%$, respectively. For the area north of $66.5^{\circ} \mathrm{N}$, we estimate the yearly accumulation at the surface and the yearly net deposition at 117 (58 Mg during 
Table 3. Impact of snowpacks on deposition.

\begin{tabular}{|c|c|c|c|c|c|c|c|c|c|}
\hline Region & $\begin{array}{l}\text { Gross } \\
\text { deposition to all } \\
\text { surfaces }(\mathrm{Mg})\end{array}$ & $\begin{array}{l}\text { Gross } \\
\text { deposition to } \\
\text { snowpacks }(\mathrm{Mg})\end{array}$ & $\begin{array}{l}\text { Fraction of } \\
\text { gross deposition } \\
\text { received by } \\
\text { snowpacks }(\%)\end{array}$ & $\begin{array}{l}\text { Net } \\
\text { deposition } \\
\text { to all } \\
\text { surfaces }(\mathrm{Mg})\end{array}$ & $\begin{array}{l}\text { Net } \\
\text { deposition to } \\
\text { snowpacks }(\mathrm{Mg})\end{array}$ & $\begin{array}{l}\text { Fraction of } \\
\text { net deposition } \\
\text { received by } \\
\text { snowpacks }(\%)\end{array}$ & $\begin{array}{l}\text { Rapid } \\
\text { revolatilization } \\
\text { as a fraction of } \\
\text { gross deposition to } \\
\text { snowpacks }(\%)\end{array}$ & $\begin{array}{l}\text { Net gain by } \\
\text { snowpacks (Mg) }\end{array}$ & $\begin{array}{l}\text { Transfer to } \\
\text { surfaces } \\
\text { underlying } \\
\text { snowpacks }(\mathrm{Mg})\end{array}$ \\
\hline \multicolumn{10}{|l|}{ Spring } \\
\hline 30 to $45^{\circ} \mathrm{N}$ & 242 & 13 & 6 & 237 & 8 & 3 & 39 & -0.4 & 9 \\
\hline 45 to $60^{\circ} \mathrm{N}$ & 196 & 54 & 27 & 163 & 21 & 13 & 61 & -2.8 & 23 \\
\hline 60 to $66.5^{\circ} \mathrm{N}$ & 59 & 38 & 65 & 30 & 10 & 34 & 73 & -1.1 & 11 \\
\hline 66.5 to $90^{\circ} \mathrm{N}$ & 205 & 189 & 92 & 63 & 47 & 74 & 75 & 4.3 & 42 \\
\hline Arctic marine surfaces & 171 & 157 & 92 & 53 & 39 & 73 & 75 & 4.5 & 34 \\
\hline Arctic terrestrial surfaces & 34 & 32 & 94 & 10 & 8 & 78 & 76 & -0.1 & 8 \\
\hline Hudson Bay System & 15 & 15 & 97 & 4 & 4 & 89 & 75 & -0.3 & 4 \\
\hline \multicolumn{10}{|l|}{ Year } \\
\hline 30 to $45^{\circ} \mathrm{N}$ & 867 & 49 & 6 & 848 & 30 & 4 & 39 & 0.0 & 30 \\
\hline 45 to $60^{\circ} \mathrm{N}$ & 662 & 132 & 20 & 586 & 56 & 10 & 57 & 0.0 & 56 \\
\hline 60 to $66.5^{\circ} \mathrm{N}$ & 172 & 71 & 41 & 125 & 23 & 19 & 67 & 0.0 & 23 \\
\hline 66.5 to $90^{\circ} \mathrm{N}$ & 350 & 263 & 75 & 153 & 66 & 43 & 75 & 0.5 & 66 \\
\hline Arctic marine surfaces & 266 & 208 & 78 & 108 & 50 & 46 & 76 & 0.4 & 50 \\
\hline Arctic terrestrial surfaces & 84 & 55 & 65 & 45 & 16 & 35 & 71 & 0.1 & 16 \\
\hline Hudson Bay System & 28 & 21 & 74 & 14 & 7 & 49 & 66 & 0.0 & 7 \\
\hline
\end{tabular}

spring) and 153 (63 Mg during spring) Mg, respectively (Table 1). This estimate of yearly net deposition is at the high end of the 80 - to $140-\mathrm{Mg} \mathrm{yr}^{-1}$ estimate provided recently by four different models (AMAP, 2011). However, none of the four models represents the dynamic revolatilization of mercury from snowpacks. The dynamic snowpack model's estimates of stronger revolatilization and greater net deposition suggest that the cycling of mercury between the atmosphere and snowpacks within the Arctic Circle may be more active than previously thought.

Over marine and terrestrial surfaces north of $66.5^{\circ} \mathrm{N}$, yearly gross deposition is estimated at 266 and $84 \mathrm{Mg}$, respectively (Table 3 ). Even though a substantially higher fraction of yearly gross deposition is received by snowpacks over marine $(78 \%)$ than terrestrial $(65 \%)$ surfaces and the average annual rapid revolatilization of mercury deposited onto snowpacks is slightly stronger over marine $(76 \%)$ than terrestrial $(71 \%)$ surfaces, we estimate that the yearly net deposition is also considerably greater over marine $(108 \mathrm{Mg})$ than terrestrial $(45 \mathrm{Mg})$ surfaces. Moreover, while $49 \%$ of the yearly net deposition is received during spring over marine surfaces, only $21 \%$ of the yearly total is received over terrestrial surfaces during spring. This agrees with previous findings that AMDE-associated deposition does not penetrate significantly inland (Landers et al., 1995; Snyder-Conn et al., 1997; Bargagli et al., 2005; Constant et al., 2007; St. Louis et al., 2007; Brooks et al., 2008b). We further estimate that $58 \mathrm{Mg}$ of yearly net deposition (14 Mg during spring) enters ocean waters within the Arctic Circle directly while $50 \mathrm{Mg}$ (34 Mg during spring) enters indirectly via the melting of snowpacks (Table 3, Figs. 7b, 8). We also estimate that $29 \mathrm{Mg}$ of yearly net deposition (2 Mg during spring) is deposited directly to terrestrial surfaces within the Arctic Circle while $16 \mathrm{Mg}$ ( $8 \mathrm{Mg}$ during spring) are deposited indirectly via the melting of snowpacks. It is unknown what fraction of the estimated $45 \mathrm{Mg}$ of yearly net deposition to arctic terrestrial surfaces eventually reaches the Arctic Ocean through runoff. Terrestrial and marine snowpacks north of $66.5^{\circ} \mathrm{N}$ are estimated to have gained an average of 0.1 and $0.4 \mathrm{Mg} \mathrm{yr}^{-1}$, respectively, over the 5-year (2005-2009) period, likely through burial by snow accumulation.

Figure $7 \mathrm{~b}$ presents the distribution of total mercury emission from the surface as a fraction of gross mercury deposition, as simulated by SORun and averaged over 20052009. These emissions exclude anthropogenic emissions (Sect. 3.3.2). The fraction is close to or exceeds $100 \%$ in Hudson Bay, the High Arctic and Greenland (discussed above). In midlatitude regions, total emission amounts to $\sim 25 \%$ to well over $100 \%$ of gross deposition. On average, the fraction emitted increases from $59 \%$ polewards of $30.0^{\circ} \mathrm{N}$ to $67 \%$ polewards of $66.5^{\circ} \mathrm{N}$.

The yearly net deposition (Sect. 3.3.1) and the yearly accumulation at the surface (Sect. 3.3.2) are presented in Fig. 7c and d, respectively. Both fields tend to decrease with increasing revolatilization fractions (Fig. 7a); snowpacks appear to have a significant impact on the biogeochemical cycling of mercury. The greatest net deposition $\left(>30 \mu \mathrm{g} \mathrm{m}^{-2}\right)$ and accumulation $\left(>20 \mu \mathrm{g} \mathrm{m}^{-2}\right.$ ) values are found near regions characterized by elevated anthropogenic emissions. In midlatitude regions less affected by anthropogenic emissions, yearly net deposition and the yearly accumulation at the surface are typically $\sim 10$ to $15 \mu \mathrm{g} \mathrm{m}^{-2}$ and $\sim-10$ to $\sim 15 \mu \mathrm{g} \mathrm{m}^{-2}$, respectively. In Hudson Bay, the Arctic, and Greenland, the net deposition and yearly accumulation range from 0 to $\sim 15$ and $\sim-5$ to $\sim 10 \mu \mathrm{g} \mathrm{m}^{-2}$, respectively.

\section{Summary and conclusions}

We have described a dynamic snowpack/meltwater model for mercury that is appropriate for large-scale atmospheric mercury models. Deposited atmospheric mercury is received by the top snowpack layer. The net photoreduction of oxidized 
mercury is represented in the same layer. Mercury is transferred from the top snowpack layer to the atmosphere via molecular and turbulent diffusions, and between the top two snowpack layers via molecular diffusion. Mercury is buried in a third snowpack layer through snow accumulation.

Oxidized mercury is transferred from the snowpack to the snowpack meltwater runoff during snowmelt. Once the snowpack has melted, the runoff also receives atmospheric mercury deposition. Mercury within the runoff undergoes net photoreduction and is transferred to the atmosphere via molecular diffusion. The runoff and its mercury content are absorbed by the underlying surface.

The snowpack/meltwater model is seen to perform well in GRAHM. Simulated concentrations of mercury in snowpacks and runoff agree well with observations. Furthermore, the fraction of total mercury within the snowpack that is GEM agrees with the observations. The updated GRAHM is better able to reproduce observed wintertime atmospheric GEM concentrations. Consequently, the simulated seasonality of atmospheric GEM concentrations improved substantially at Point Petre. At Alert, the updated GRAHM's prediction of the revolatilization of AMDE-associated mercury deposition improved significantly. Given its dynamic physically-based nature, this model is deemed appropriate for long-term numerical studies on the effects of changing climate and emission scenarios. However, considering the limited number of snowpack-related observations available at this time for model verification, additional evaluation of the snowpack/meltwater model for mercury is required in detailed case studies and under conditions of particular field measurements.

Simulations by GRAHM and its new snowpack/meltwater model for mercury suggest that, on an annual basis, the average fraction of mercury deposited onto snowpacks that is revolatilized increases with latitude from $39 \%$ between 30 and $45^{\circ} \mathrm{N}$, to $57 \%$ from 45 to $60^{\circ} \mathrm{N}, 67 \%$ from 60 to $66.5^{\circ} \mathrm{N}$, and $75 \%$ polewards of $66.5^{\circ} \mathrm{N}$. Since the coverage of snowpacks also increases with latitude, yearly net deposition as a fraction of gross deposition decreases from $98 \%$ between 30 and $45^{\circ} \mathrm{N}$ to $89 \%$ between 45 and $60^{\circ} \mathrm{N}, 73 \%$ between 60 and $66.5^{\circ} \mathrm{N}$, and $44 \%$ within the Arctic Circle. Thus, our dynamic snowpack/meltwater model for mercury suggests that snowpacks provide the surface with a fairly effective barrier against atmospheric mercury. Polewards of $66.5^{\circ} \mathrm{N}$, the yearly net deposition and accumulation of mercury are estimated at 153 and $117 \mathrm{Mg}$, respectively. We estimate that 58 and $50 \mathrm{Mg}$ of mercury are deposited annually to the Arctic Ocean directly and indirectly via melting snowpacks, respectively. For terrestrial surfaces within the Arctic Circle, we estimate that 29 and $16 \mathrm{Mg}$ of mercury are deposited annually directly and indirectly via melting snowpacks, respectively. Within the Arctic Circle, multi-season snowpacks gained an average of 0.1 and $0.4 \mathrm{Mg}$ of mercury annually on land and over sea ice, respectively.
Simulations performed by GRAHM and its new snowpack/meltwater model for mercury strongly suggest that oceanic evasion produces the observed summertime maximum in atmospheric GEM concentrations at Alert. Oceanic emissions also appear to generate the summertime volatility observed in the atmospheric GEM concentrations at both Alert and Kuujjuarapik. As a result of the strong oceanic emissions, the Hudson Bay System is estimated to experience a net accumulation of $-6 \mathrm{Mg}$ during summer.

\section{Future work}

The presented dynamic snowpack/meltwater model for mercury represents a first attempt to develop such a model for inclusion in a large-scale atmospheric mercury model. Many refinements are possible. For instance, a version could be tested with multiple photochemically active layers. The reduction and oxidation of mercury in both the light and the dark could be represented separately. The stabilizing effect of halides, which promotes the retention of mercury within the snowpack, could be simulated. A representation of the formation and dissolution of PHg within the snowpack could be introduced. Finally, the snowpack model's e-folding depth, which impacts the penetration of solar radiation, could be made to vary according to the impurities in the snowpack.

Acknowledgements. This study was funded by the projects INCATPA and CARA. The former project used funding from Government of Canada Program for International Polar Year. We are deeply indebted to all those who provided us with verifying observations of atmospheric surface-level concentrations of GEM. The development of the snowpack/meltwater model would not have been successful without these observations.

Edited by: R. Cohen

\section{References}

Abbatt, J. P. D.: Interactions of atmospheric trace gases with ice surfaces: Adsorption and reaction, Chem. Rev., 103, 4783-4800, 2003.

Albert, M. R. and Shultz, E. F.: Snow and firn properties and airsnow transport processes at Summit, Greenland, Atmos. Environ., 36, 2789-2797, 2002.

Allan, C. J., Heyes, A., Roulet, N. T., St. Louis, V. L., and Rudd, J. W. M.: Spatial and temporal dynamics of mercury in Precambrian Shield upland runoff, Biogeochemistry, 52, 13-40, 2001.

AMAP: Arctic Pollution 2011, Arctic Monitoring and Assessment Programme (AMAP), Oslo, Norway, 38 pp., 2011.

Anderson, P. S., Neff, W. D.: Boundary layer physics over snow and ice, Atmos. Chem. Phys., 8, 3563-3582, doi:10.5194/acp-83563-2008, 2008.

Andersson, M. E., Gårdfeldt, K., Wängberg, I., and Strömberg, D.: Determination of Henry's law con- 
stant for elemental mercury, Chemosphere, 73, 587-592, doi:10.1016/j.chemosphere.2008.05.067, 2008a.

Andersson, M. E., Sommar, J., Gårdfeldt, K., and Lindqvist, O.: Enhanced concentrations of dissolved gaseous mercury in the surface waters of the Arctic Ocean, Mar. Chem., 110, 190-194, 2008 b.

Ariya, P. A., Khazilov, A., and Gidas, A.: Reactions of gaseous mercury with atomic and molecular halogens: Kinetics, product studies, and atmospheric implications, J. Phys. Chem. A., 106, 7310-7320, 2002.

Ariya, P. A., Dastoor, A. P., Amyot, M., Schroeder, W. H., Barrie, L., Anlauf, K., Raofie, F., Ryzhkov, A., Davignon, D., Lalonde, J., and Steffen, A.: The Arctic: a sink for mercury, Tellus, Ser. B, 56, 397-403, 2004.

Bales, R. C., Davis, R. E., and Stanley, D. A.: Ion elution through shallow homogeneous snow, Water Resour. Res., 25, 1869-1877, 1989.

Bales, R. C., Sommerfeld, R. A., Kebler, D. G.: Ionic tracer movement through a Wyoming snowpack, Atmos. Environ., 24, 27492758, 1990.

Balogh, S. J., Meyer, M. L., Hansen, N. C., Moncrief, J. F., and Gupta, S. C.: Transport of mercury from a cultivated field during snowmelt, J. Environ. Qual., 29, 871-874, 2000.

Bargagli, R., Agnorelli, C., Borghini, F., and Monaci, F.: Enhanced deposition and bioaccumulation of mercury in Antarctic terrestrial ecosystems facing a coastal polynya, Environ. Sci. Technol., 39, 8150-8155, 2005.

Bartels-Rausch, T., Huthwelker, T., Jöri, M., Gäggeler, H. W., Ammann, M.: Interaction of gaseous elemental mercury with snow surfaces: laboratory investigation, Environ. Res. Lett., 3, 045009 , doi:10.1088/1748-9326/3/4/045009, 2008.

Bartels-Rausch, T., Krysztofiak, G., Bernhard, A., Schläppi, M., Schwikowski, M., and Ammann, M.: Photoinduced reduction of divalent mercury in ice by organic matter, Chemosphere, 82 , 199-203, 2011.

Berg, T., Sekkesæter, S., Steinnes, E., Valdal, A.-K., and Wibetoe, G.: Springtime depletion of mercury in the European Arctic as observed at Svalbard, Sci. Total Environ., 304, 43-51, 2003.

Bishop, K., Lee, Y.-H., Pettersson, C., and Allard, B.: Methylmercury output from the Svartberget catchment in Northern Sweden during spring flood, Water Air Soil Poll., 80, 445-454, 1995.

Blanchard, P., Froude, F. A., Martin, J. B., Dryfhout-Clark, H., and Woods, J. T.: Four years of continuous total gaseous mercury (TGM) measurements at sites in Ontario, Canada, Atmos. Environ., 36, 3735-3743, 2002.

Boutron, C. F., Vandal, G. M., Fitzgerald, W. F., and Ferrari, C. P.: A forty year record of mercury in central Greenland snow, Geophys. Res. Lett., 25, 3315-3318, 1998.

Brooks, S. B., Saiz-Lopez, A., Skov, H., Lindberg, S. E., Plane, J. M. C., and Goodsite, M. E.: The mass balance of mercury in the springtime arctic environment, Geophys. Res. Lett., 33, L13812, doi:10.1029/2005GL025525, 2006.

Brooks, S., Arimoto, R., Lindberg, S., and Southworth, G.: Antarctic polar plateau snow surface conversion of deposited oxidized mercury to gaseous elemental mercury with fractional long-term burial, Atmos. Environ., 42, 2877-2884, 2008a.

Brooks, S., Lindberg, S., Southworth, G., and Arimoto, R.: Springtime atmospheric mercury speciation in the McMurdo, Antarctica coastal region, Atmos. Environ., 42, 2885-2893, 2008 b.
Christensen, J. H., Brandt, J., Frohn, L. M., Skov, H.: Modelling of mercury in the Arctic with the Danish Eulerian Hemispheric Model, Atmos. Chem. Phys., 4, 2251-2257, doi:10.5194/acp-42251-2004, 2004.

Cobbett, F. D., Steffen, A., Lawson, G., and Van Heyst, B. J.: GEM fluxes and atmospheric mercury concentrations (GEM, RGM and $\mathrm{Hg}^{p}$ ) in the Canadian Arctic at Alert, Nunavut, Canada (February-June 2005), Atmos. Environ., 41, 6527-6543, 2007.

Cole, A. S. and Steffen, A.: Trends in long-term gaseous mercury observations in the Arctic and effects of temperature and other atmospheric conditions, Atmos. Chem. Phys., 10, 4661-4772, doi:10.5194/acp-10-4661-2010, 2010.

Constant, P., Poissant, L., Villemur, R., Yumvihoze, E., and Lean, D.: Fate of inorganic mercury and methyl mercury within the snow cover in the low arctic tundra on the shore of Hudson Bay (Québec, Canada), J. Geophys. Res., 112, D08309, doi:10.1029/2006JD007961, 2007.

Côté, J., Desmarais, J.-G., Gravel, S., Méthot, A., Patoine, A., Roch, M., and Staniforth, A.: The operational CMC-MRB Global Environmental Multiscale (GEM) Model: Part II - Results, Mon. Weather Rev., 126, 1397-1418, 1998a.

Côté, J., Gravel, S., Méthot, A., Patoine, A., Roch, M., and Staniforth, A.: The operational CMC-MRB Global Environmental Multiscale (GEM) Model: Part I - Design considerations and formulation, Mon. Wea. Rev., 126, 1373-1395, 1998 b.

Cozic, J., Verheggen, B., Weingartner, E., Crosier, J., Bower, K. N., Flynn, M., Coe, H., Henning, S., Steinbacher, M., Henne, S., Collaud Coen, M., Petzold, A., Baltensperger, U.: Chemical composition of free tropospheric aerosol for PM1 and coarse mode at the high alpine site Jungfraujoch, Atmos. Chem. Phys., 8, 407423, doi:10.5194/acp-8-407-2008, 2008.

Dastoor, A. P., Davignon, D., Theys, N., Van Roozendael, M., Steffen, A., and Ariya, P. A.: Modeling dynamic exchange of gaseous elemental mercury at polar sunrise, Environ. Sci. Technol., 42, 5183-5188, doi:10.1021/es800291w, 2008.

Domine, F., Albert, M., Huthwelker, T., Jacobi, H.-W., Kokhanovsky, A. A., Lehning, M., Picard, G., and Simpson, W. R.: Snow physics as relevant to snow photochemistry, Atmos. Chem. Phys., 8, 171-208, doi:10.5194/acp-8-171-2008, 2008.

Dommergue, A., Ferrari, C. P., Gauchard, P.-A., and Boutron, C. F.: The fate of mercury species in a sub-arctic snowpack during snowmelt, Geophys. Res. Lett., 30, 1621, doi:10.1029/2003GL017308, 2003.

Dommergue, A., Bahlmann, E., Ebinghaus, R., Ferrari, C., and Boutron, C.: Laboratory simulation of $\mathrm{Hg}^{0}$ emissions from a snowpack, Anal. Bioanal. Chem., 388, 319-327, 2007.

Dommergue, A., Larose, C., Faïn, X., Clarisse, O., Foucher, D., Hintelmann, H., Schneider, D., and Ferrari, C. P.: Deposition of mercury species in the $\mathrm{Ny}$-Ålesund area $\left(79^{\circ} \mathrm{N}\right)$ and their transfer during snowmelt, Environ. Sci. Technol., 44, 901-907, doi:10.1021/es902579m, 2010.

Donohoue, D. L., Bauer, D., and Hynes, A. J.: Temperature and pressure dependent rate coefficients for the reaction of $\mathrm{Hg}$ with $\mathrm{Cl}$ and the reaction of $\mathrm{Cl}$ with $\mathrm{Cl}$ : A pulsed laser photolysispulsed laser induced fluorescence study, J. Phys. Chem. A., 109, 7732-7741, 2005.

Douglas, T. A., Sturm, M., Simpson, W. R., Blum, J. D., AlvarezAviles, L., Keeler, G. J., Perovich, D. K., Biswas, A., and John- 
son, K.: Influence of snow and ice crystal formation and accumulation on mercury deposition to the Arctic, Environ. Sci. Technol., 42, 1542-1551, 2008.

Durnford, D. and Dastoor, A.: The behavior of mercury in the cryosphere: A review of what we know from observations, J. Geophys. Res., 116, D06305, doi:10.1029/2010JD014809, 2011. Durnford, D., Dastoor, A., Figueras-Nieto, D., and Ryjkov, A.: Long range transport of mercury to the Arctic and across Canada, Atmos. Chem. Phys., 10, 6063-6086, doi:10.5194/acp-10-60632010, 2010.

Durnford, D. A., Dastoor, A. P., Steen, A. O., Berg, T., Ryzhkov, A., Figueras-Nieto, D., Hole, L. R., Pfaffhuber, K. A., and Hung, H.: How relevant is the deposition of mercury onto snowpacks? Part 1: A statistical study on the impact of environmental factors, Atmos. Chem. Phys., 12, 9221-9249, doi:10.5194/acp-12-92212012, 2012.

Fain, X., Ferrari, C. P., Gauchard, P.-A., Magand, O., Boutron, C.: Fast depletion of gaseous elemental mercury in the Kongsvegen Glacier snowpack in Svalbard, Geophys. Res. Lett., 33, L06826, doi:10.1029/2005GL025223, 2006.

Faïn, X., Grangeon, S., Bahlmann, E., Fritsche, J., Obrist, D., Dommergue, A., Ferrari, C. P., Cairns, W., Ebinghaus, R., Barbante, C., Cescon, P., and Boutron, C.: Diurnal production of gaseous mercury in the alpine snowpack before snowmelt, J. Geophys. Res., 112, D21311, doi:10.1029/2007JD008520, 2007.

Faïn, X., Ferrari, C. P., Dommergue, A., Albert, M., Battle, M., Arnaud, L., Barnola, J.-M., Cairns, W., Barbante, C., Boutron, C.: Mercury in the snow and firn at Summit Station, Central Greenland, and implications for the study of past atmospheric mercury levels, Atmos. Chem. Phys., 8, 3441-3457, doi:10.5194/acp-83441-2008, 2008.

Faïn, X., Ferrari, C. P., Dommergue, A., Albert, M. R., Battle, M., Severinghaus, J., Arnaud, L., Barnola, J.-M., Cairns, W., Barbante, C., and Boutron, C.: Polar firn air reveals large-scale impact of anthropogenic mercury emissions during the 1970s, P. Natl. Acad. Sci. USA, 106, 16114-16119, doi:10.1073/pnas.0905117106, 2009.

Fatnassi, H., Boulard, T., Poncet, C., and Chave, M.: Optimisation of greenhouse insect screening with computational fluid dynamics, Biosyst. Eng., 93, 301-312, 2006.

Ferrari, C. P., Dommergue, A., and Boutron, C. F.: Profiles of mercury in the snow pack at Station Nord, Greenland shortly after polar sunrise, Geophys. Res. Lett., 31, L03401, doi:10.1029/2003GL018961, 2004a.

Ferrari, C. P., Dommergue, A., Boutron, C. F., Skov, H., Goodsite, M., and Jensen, B.: Nighttime production of elemental gaseous mercury in interstitial air of snow at Station Nord, Greenland, Atmos. Environ., 38, 2727-2735, 2004b.

Ferrari, C. P., Gauchard, P.-A., Aspmo, K., Dommergue, A., Magand, O., Bahlmann, E., Nagorski, S., Temme, C., Ebinghaus, R., Steffen, A., Banic, C., Berg, T., Planchon, F., Barbante, C., Cescon, P., Boutron, C. F.: Snow-to-air exchanges of mercury in an Arctic seasonal snow pack in Ny-Ålesund, Svalbard, Atmos. Environ., 39, 7633-7645, 2005.

Ferrari, C. P., Padova, C., Faïn, X., Gauchard, P.-A., Dommergue, A., Aspmo, K., Berg, T., Cairns, W., Barbante, C., Cescon, P., Kaleshke, L., Richter, A., Wittrock, F., and Boutron, C.: Atmospheric mercury depletion event study in Ny-Alesund (Svalbard) in spring 2005. Deposition and transformation of $\mathrm{Hg}$ in surface snow during springtime, Sci. Total Environ., 397, 167-177, 2008.

Fouquart, Y. and Bonnel, B.: Computations of solar heating of the earth's atmosphere: a new parameterization, Contrib. Atmos. Phys., 53, 35-62, 1980.

Galbavy, E. S., Anastasio, C., Lefer, B., and Hall, S.: Light penetration in the snowpack at Summit, Greenland: Part 2 nitrate photolysis, Atmos. Environ., 41, 5091-5100, 2007.

Garand, L. and Mailhot, J.: The influence of infrared radiation on numerical weather forecasts, in Proceedings of the $7^{\text {th }}$ Conference on Atmospheric Radiation, J146-J151, American Meteorological Society, USA, 1990.

Garbarino, J. R., Snyder-Conn, E., Leiker, T. J., and Hoffman, G. L.: Contaminants in Arctic snow collected over Northwest Alaskan sea ice, Water, Air, Soil Pollut., 139, 183-214, 2002.

Gbor, P. K., Wen, D., Meng, F., Yang, F., and Sloan, J. J.: Sloan Modeling of mercury emission, transport and deposition in North America, Atmos. Environ., 41, 1135-1149, 2007.

Goulet, R. R., Holmes, J., Page, B., Poissant, L., Siciliano, S. D., Lean, D. R. S., Wang, F., Amyot, M., and Tessier, A.: Mercury transformations and fluxes in sediments of a riverine wetland, Geochim. Cosmochim. Ac., 71, 3393-3406, 2007.

Grannas, A. M., Jones, A. E., Dibb, J., Ammann, M., Anastasio, C., Beine, H. J., Bergin, M., Bottenheim, J., Boxe, C. S., Carver, G., Chen, G., Crawford, J. H., Dominé, F., Frey, M. M., Guzmán, M. I., Heard, D. E., Helmig, D., Hoffmann, M. R., Honrath, R. E., Huey, L. G., Hutterli. M., Jacobi, H. W., Klán, P., Lefer, B., McConnell, J., Plane, J., Sander, R., Savarino, J., Shepson, P. B., Simpson, W. R., Sodeau, J. R., von Glasow, R., Weller, R., Wolff, E. W., Zhu, T.: An overview of snow photochemistry: evidence, mechanisms and impacts, Atmos. Chem. Phys., 7, 4329-4373, doi:10.5194/acp-7-4329-2007, 2007.

Hall: The gas phase oxidation of elemental mercury by ozone, Water Air Soil Poll., 80, 301-315, 1995.

Hansen, K. M., Halsall, C. J., and Christensen, J. H.: A dynamic model to study the exchange of gas-phase persistent organic pollutants between air and a seasonal snowpack, Environ. Sci. Technol., 40, 2644-2652, doi:10.1021/es051685b, 2006.

Hare, A., Stern, G. A., Macdonald, R. W., Kuzyk, Z. Z., and Wang, F.: Contemporary and preindustrial mass budgets of mercury in the Hudson Bay Marine System: The role of sediment recycling, Sci. Total Environ., 406, 190-204, doi:10.1016/j.scitotenv.2008.07.033, 2008.

Hedgecock, I. M., Pirrone, N., and Sprovieri, F.: Chasing quicksilver northward: mercury chemistry in the Arctic troposphere, Environ. Chem., 5, 131-134, 2008.

Heidam, N. Z., Christensen, J., Wåhlin, P., and Skov, H.: Arctic atmospheric contaminants in NE Greenland: levels, variations, origins, transport, transformations and trends 1990-2001, Sci. Total Environ., 331, 5-28, 2004

Henderson, P. J., McMartin, I., Hall, G. E., Percival, J. B., and Walker, D. A.: The chemical and physical characteristics of heavy metals in humus and till in the vicinity of the base metal smelter at Flin Flon, Manitoba, Canada, Environmental Geology, 34, 39-58, 1998.

Hirdman, D., Aspmo, K., Burkhart, J. F., Eckhardt, S., Sodemann, H., and Stohl, A.: Transport of mercury in the Arctic atmosphere: evidence for a spring-time net sink and summer-time source, Geophys. Res. Lett., 36, L12814, doi:10.1029/2009GL038345, 2009 . 
Holmes, C. D., Jacob, D. J., Corbitt, E. S., Mao, J., Yang, X., Talbot, R., and Slemr, F.: Global atmospheric model for mercury including oxidation by bromine atoms, Atmos. Chem. Phys., 10, 12037-12057, doi:10.5194/acp-10-12037-2010, 2010.

Jackson, T. A.: Long-range atmospheric transport of mercury to ecosystems, and the importance of anthropogenic emissions - a critical review and evaluation of the published evidence, Environ. Rev., 5, 99-120, 1997.

Jitaru, P., Gabrielli, P., Marteel, A., Plane, J. M. C., Planchon, F. A. M., Gauchard, P.-A., Ferrari, C. P., Boutron, C. F., Adams, F. C., Hong, S., Cescon, P., and Barbante, C.: Atmospheric depletion of mercury over Antarctica during glacial periods, Nat. Geosci., 2, 505-508, doi:10.1038/ngeo549, 2009.

Johnson, K. P., Blum, J. D., Keeler, G. J., and Douglas, T. A.: Investigation of the deposition and emission of mercury in arctic snow during an atmospheric mercury depletion event, J. Geophys. Res., 113, D17304, doi:10.1029/2008JD009893, 2008.

Kain, J. S. and Fritsch, J. M.: A one-dimensional entraining/detraining plume model and its application in convective parameterization, J. Atmos. Sci., 47, 2784-2802, 1990.

Kellerhals, M., Beauchamp, S., Belzer, W., Blanchard, P., Froude, F., Harvey, B., McDonald, K., Pilote, M., Poissant, L., Puckett, K., Schroeder, W., Steffen, A., and Tordon, R.: Temporal and spatial variability of total gaseous mercury in Canada: results from the Canadian Atmospheric Mercury Measurement Network (CAMNet), Atmos. Environ., 37, 1003-1011, 2003.

King, M. D. and Simpson, W. R.: Extinction of UV radiation in Arctic snow at Alert, Canada $\left(82^{\circ} \mathrm{N}\right)$, J. Geophys. Res., 106, 1249912507, 2001.

Kirk, J. L., St. Louis, V. L., and Sharp, M. J.: Rapid reduction and emission of mercury deposited into snowpacks during atmospheric mercury depletion events at Churchill, Manitoba, Canada, Environ. Sci. Technol., 40, 7590-7596, 2006.

Kirk, J. L., St. Louis, V. L., Hintelmann, H., Lehnherr, I., Else, B., and Poissant, L., Methylated mercury species in marine waters of the Canadian high and sub Arctic. Environ. Sci. Tech., 42, 83678373, doi:10.1021/es801635m, 2008.

Kuhn, M.: The nutrient cycle through snow and ice, a review, Aquat. Sci., 63, 150-167, 2001.

Lahoutifard, N., Poissant, L., and Scott, S. L.: Scavenging of gaseous mercury by acidic snow at Kuujjuarapik, Northern Québec, Sci. Total Environ., 355, 118-126, 2006.

Lalonde, J. D., Poulain, A. J., and Amyot, M.: The role of mercury redox reactions in snow on snow-to-air mercury transfer, Environ. Sci. Technol., 36, 174-178, 2002.

Lalonde, J. D., Amyot, M., Doyon, M.-R., and Auclair, J.-C.: Photoinduced $\mathrm{Hg}(\mathrm{II})$ reduction in snow from the remote and temperate Experimental lakes Area (Ontario, Canada), J. Geophys. Res., 108, 4200, doi:10.1029/2001JD001534, 2003.

Landers, D. H., Ford, J., Gubala, C., Monetti, M., Lasorsa, B. K., and Martinson, J.: Mercury in vegetation and lake sediments from the U.S. Arctic, Water Air Soil Poll., 80, 591-601, 1995.

Larose, C., Dommergue, A., De Angelis, M., Cossa, D., Averty, B., Marusczak, N., Soumis, N., Schneider, D., and Ferrari, C.: Springtime changes in snow chemistry lead to new insights into mercury methylation in the Arctic, Geochim. Cosmochim. Ac., 74, 6263-6275, doi:10.1016/j.gca.2010.08.043, 2010.

Lee-Taylor, J., Madronich, S.: Calculation of actinic fluxes with a coupled atmosphere-snow radiative transfer model, J. Geophys.
Res., 107, D24, 4796, doi:10.1029/2002JD002084, 2002.

Lin, C.-J., Pongprueksa, P., Lindberg, S. E., Pehkonen, S. O., Byun, D., and Jang, C.: Scientific uncertainties in atmospheric mercury models I: Model science evaluation, Atmos. Environ., 40, 29112928, 2006.

Lindberg, S. E., Brooks, S., Lin, C.-J., Scott, K. J., Landis, M. S., Stevens, R. K., Goodsite, M., and Richter, A.: Dynamic oxidation of gaseous mercury in the Arctic troposphere at Polar Sunrise, Environ. Sci. Technol., 36, 1245-1256, 2002.

Loewen, M., Kang, S., Armstrong, D., Zhang, Q., Tomy, G., and Wang, F.: Atmospheric transport of mercury to the Tibetan Plateau, Environ. Sci. Technol., 41, 7632-7638, 2007.

Loseto, L. L., Lean, D. R. S., and Siciliano, S. D.: Snowmelt sources of methylmercury to High Arctic ecosystems, Environ. Sci. Technol., 38, 3004-3010, 2004.

Loux, N. T.: Monitoring cyclical air/water elemental mercury exchange, J. Environ. Monit., 3, 43-48, doi:10.1039/b005545j, 2001.

Lu, J. Y., Schroeder, W. H., Barrie, L. A., Steffen, A., Welch, H. E., Martin, K., Lockhart, L., Hunt, R. V., Boila, G., and Richter, A.: Magnification of atmospheric mercury deposition to polar regions in springtime: the link to tropospheric ozone depletion chemistry, Geophys. Res. Lett., 28, 3219-3222, 2001.

Mann, J. L., Long, S. E., Shuman, C. A., and Kelly, W. R.: Determination of mercury content in a shallow firn core from Greenland by isotope dilution inductively coupled plasma mass spectrometry, Water Air Soil Poll., 163, 19-32, 2005.

Mann, E., Meyer, T., Mitchell, C. P. J., and Wania, F.: Mercury fate in ageing and melting snow: Development and testing of a controlled laboratory system, J. Environ. Monit., 13, 2695-2702, 2011.

Marusczak, N., Larose, C., Dommergue, A., Yumvihoze, E., Lean, D., Nedjai, R., and Ferrari, C.: Total mercury and methylmercury in high altitude surface snow from the French Alps, Sci. Tot. Environ., 409, 3949-3954, 2011.

Mason, R.: Mercury emissions from natural processes and their importance in the global mercury cycle, in Mercury fate and transport in the global atmosphere, 173-191, Springer USA, 2009.

Maupetit, F., Wagenbach, D., Weddeling, P., and Delmas, R. J.: Seasonal fluxes of major ions to a high altitude cold alpine glacier, Atmos. Environ., 29, 1-9, 1995.

McMartin, I., Henderson, P. J., and Nielsen, E.: Impact of a base metal smelter on the geochemistry of soils of the Flin Flon region, Manitoba and Saskatchewan, Can. J. Earth Sci., 36, 141$160,1999$.

Mitchell, C. P. J., Branfireun, B. A., and Kolka, R. K.: Assessing sulfate and carbon controls on net methylmercury production in peatlands: An in situ mesocosm approach, Appl. Geochem., 23, 503-518, 2008a.

Mitchell, C. P. J., Branfireun, B. A., and Kolka, R. K.: Total mercury and methylmercury dynamics in upland-peatland watersheds during snowmelt, Biogeochemistry, 90, 225-241, doi:10.1007/s10533-008-9246-z, 2008b.

Nelson, S. J., Johnson, K. B., Weathers, K. C., Loftin, C. S., Fernandez, I. J., Kahl, J. S., and Krabbenhoft, D. P.: A comparison of winter mercury accumulation at forested and no-canopy sites measured with different snow sampling techniques, Appl. Geochem., 23, 384-398, 2008. 
Outridge, P. M., Macdonald, R. W., Wang, F., Stern, G. A., and Dastoor, A. P.: A mass balance inventory of mercury in the Arctic Ocean, Environ. Chem, 5, 89-111, doi:10.1071/EN08002, 2008.

Pacyna, E. G., Pacyna, J. M., Sundseth, K., Munthe, J., Kindbom, K., Wilson, S., Steenhuisen, F., and Maxson, P.: Global emission of mercury to the atmosphere from anthropogenic sources in 2005 and projections to 2020, Atmos. Environ. 44, 2487-2499, doi:10.1016/j.atmosenv.2009.06.009, 2010.

Pehkonen, S. O. and Lin, C.-J.: Aqueous photochemistry of mercury with organic acids, J. Air Waste Manage., 48, 144-150, 1998.

Perovich, D. K.: Light reflection and transmission by a temperate snow cover, J. Glaciol., 53, 201-210, 2007.

Peterson, M., Barber, D., and Green, S.: Monte Carlo modeling and measurements of actinic flux levels in Summit, Greenland snowpack, Atmos. Environ., 36, 2545-2551, 2002.

Planchon, F. A. M., Gabrielli, P., Gauchard, P. A., Dommergue, A., Barbante, C., Cairns, W. R. L., Cozzi, G., Nagorski, S. A., Ferrari, C. P., Boutron, C. F., Capodaglio, G., Cescon, P., Varga, A., and Wolff, E. W.: Direct determination of mercury at the subpicogram per gram level in polar snow and ice by ICP-SFMS, J. Anal. Atom. Spectrom., 19, 823-830, 2004.

Poissant, L. and Pilote, M.: Time series analysis of atmospheric mercury in Kuujjuarapik/Whapmagoostui (Québec), J. de Phys. IV: JP, 107, 1079-1082, 2003.

Poissant, L., Amyot, M., Pilote, M., and Lean, D.: Mercury water-air exchange over the upper St. Lawrence River and Lake Ontario, Environ. Sci. Technol., 34, 3069-3078, doi:10.1021/es990719a, 2000.

Poulain, A. J., Lalonde, J. D., Amyot, M., Shead, J. A., Raofie, F., and Ariya, P. A.: Redox transformations of mercury in an Arctic snowpack at springtime, Atmos. Environ., 38, 6763-6774, 2004.

Poulain, A. J., Garcia, E., Amyot, M., Campbell, P. G. C., and Ariya, P. A.: Mercury distribution, partitioning and speciation in coastal vs. inland High Arctic snow, Geochim. Cosmochim. Ac., 71, 3419-3431, 2007a.

Poulain, A. J., Roy, V., and Amyot, M.: Influence of temperate mixed and deciduous tree covers on $\mathrm{Hg}$ concentrations and photoredox transformations in snow, Geochim. Cosmochim. Ac., 71, 2448-2462, 2007b

Prestbo, E. M. and Gay, D. A.: Wet deposition of mercury in the U.S. and Canada, 1996-2005: Results and analysis of the NADP mercury deposition network (MDN), Atmos. Environ., 43, 42234233, 2009.

Raofie, F. and Ariya, P. A.: Kinetics and products study of the reaction of BrO radicals with gaseous mercury, J. Phys., 107, 11191121, 2003.

Ryaboshapko, A., Bullock, R., Christensen, J., Cohen, M., Dastoor, A., Ilyin, I., Petersen, G., Syrakov, D., Artz, R., Davignon, D., Draxler, R., and Munthe, J.: Intercomparison study of atmospheric mercury models: 1 . Comparison of models with shortterm measurements, Sci. Total Environ., 376, 228-240, 2007a.

Ryaboshapko, A., Bullock, R., Christensen, J., Cohen, M., Dastoor, A., Ilyin, I., Petersen G., Syrakov, D., Travnikov, O., Artz, R., Davignon, D., Draxler, R., Munthe, J., and Pacyna, J.: Intercomparison Study of Atmospheric Mercury Models: 2. Modelling results vs. long-term observations and comparison of country deposition budgets, Sci. Total Environ., 377, 319-333, 2007b.

Schuster, P. F., Krabbenhoft, D. P., Naftz, D. L., Cecil, L. D., Olson, M. K., Dewild, J. F., Susong, D. D., Green, J. R., and Abbott, M.
L.: Atmospheric mercury deposition during the last 270 years: A glacial ice core record of natural and anthropogenic sources, Environ. Sci. Technol., 36, 2303-2310, 2002.

Seigneur, C., Abeck, H., Chia, G., Reinhard, M., Bloom, N. S. Prestbo, E., and Saxena, P.: Mercury adsorption to elemental carbon (soot) particles and atmospheric particulate matter, Atmos. Environ, 32, 2649-2657, 1998.

Sherman, L. S., Blum, J. D., Johnson, K. P., Keeler, G. J., Barres, J. A., and Douglas, T. A.: Mass-independent fractionation of mercury isotopes in Arctic snow driven by sunlight, Nat. Geosci., 3, 173-177, doi:10.1038/ngeo758, 2010.

Shetty, S. K., Lin, C.-J., Streets, D. G., and Jang, C.: Model estimate of mercury emission from natural sources in East Asia, Atmos. Environ., 42, 8674-8685, 2008.

Simpson, W. R., King, M. D., Beine, H. J., Honrath, R. E., and Zhou, X.: Radiation-transfer modeling of snow-pack photochemical processes during ALERT 2000, Atmos. Environ., 36, 2663 2670, 2002.

Simpson, W. R., Carlson, D., Hönninger, G., Douglas, T. A., Sturm, M., Perovich, D., and Platt, U.: First-year sea-ice contact predicts bromine monoxide $(\mathrm{BrO})$ levels at Barrow, Alaska better than potential frost flower contact, Atmos. Chem. Phys., 7, 621-627, doi:10.5194/acp-7-621-2007, 2007a.

Simpson, W. R., von Glasow, R., Riedel, K., Anderson, P., Ariya, P., Bottenheim, J., Burrows, J., Carpenter, L. J., Frieß, U., Goodsite, M. E., Heard, D., Hutterli, M., Jacobi, H.-W., Kaleschke, L., Neff, B., Plane, J., Platt, U., Richter, A., Roscoe, H., Sander, R., Shepson, P., Sodeau, J., Steffen, A., Wagner, T., Wolff, E.: Halogens and their role in polar boundary-layer ozone depletion, Atmos. Chem. Phys., 7, 4375-4418, doi:10.5194/acp-7-4375-2007, 2007b.

Skov, H., Christensen, J. H., Goodsite, M. E., Heidam, N. Z., Jensen, B., Wåhlin, P., and Geernaert, G.: Fate of elemental mercury in the Arctic during atmospheric mercury depletion episodes and the load of atmospheric mercury to the Arctic, Environ. Sci. Technol., 38, 2373-2382, 2004.

Snyder-Conn, E., Garbarino, J. R., Hoffman, G. L., and Oelkers, A.: Soluble trace elements and total mercury in Arctic Alaskan snow, Arctic, 50, 201-215, 1997.

Soerensen, A. L., Sunderland, E. M., Holmes, C. D., Jacob, D. J., Yantosca, R. M., Skov, H., Christensen, J. H., Strode, S. A., and Mason, R. P.: An improved global model for air-sea exchange of mercury: High concentrations over the North Atlantic, Environ, Sci. Technol., 44, 8574-8580, 2010.

Sommar, J., Wängberg, I., Berg, T., Gårdfeldt, K., Munthe, J., Richter, A., Urba, A., Wittrock, F., Schroeder, W. H.: Circumpolar transport and air-surface exchange of atmospheric mercury at Ny-Ålesund $\left(79^{\circ} \mathrm{N}\right)$, Svalbard, spring 2002, Atmos. Chem. Phys., 7, 151-166, doi:10.5194/acp-7-151-2007, 2007.

Steen, A. O., Berg, T., Dastoor, A. P., Durnford, D. A., Hole, L. R., and Phaffhuber, K. A.: Dynamic exchange of gaseous elemental mercury during polar night and day, Atmos. Environ., 43, 56045610, 2009.

Steffen, A., Schroeder, W., Bottenheim, J., Narayan, J., and Fuentes, J. D.: Atmospheric mercury concentrations: measurements and profiles near snow and ice surfaces in the Canadian Arctic during Alert 2000, Atmos. Environ., 36, 2653-2661, 2002.

Steffen, A., Schroeder, W., Macdonald, R., Poissant, L., and Konoplev, A.: Mercury in the Arctic atmosphere: An analysis of eight 
years of measurements of GEM at Alert (Canada) and a comparison with observations at Amderma (Russia) and Kuujjuarapik (Canada), Sci. Total Environ., 342, 185-198, 2005.

Steffen, A., Douglas, T., Amyot, M., Ariya, P., Aspmo, K., Berg, T., Bottenheim, J., Brooks, S., Cobbett, F., Dastoor, A., Dommergue, A., Ebinghaus, R., Ferrari, C., Gardfeldt, K., Goodsite, M. E., Lean, D., Poulain, A. J., Scherz, C., Skov, H., Sommar, J., Temme, C.: A synthesis of atmospheric mercury depletion event chemistry in the atmosphere and snow, Atmos. Chem. Phys., 8, 1445-1482, doi:10.5194/acp-8-1445-2008, 2008.

St. Louis, V. L., Sharp, M. J., Steffen, A., May, A., Barker, J., Kirk, J. L., Kelly, D. J. A., Arnott, S. E., Keatley, B., and Smol, J. P.: Some sources and sinks of monomethyl and inorganic mercury on Ellesmere Island in the Canadian High Arctic, Environ. Sci. Technol., 39, 2686-2701, 2005.

St. Louis, V. L., Hintelmann, H., Graydon, J. A., Kirk, J. L., Barker, J., Dimock, B., Sharp, M. J., and Lehnherr, I.: Methylated mercury species in Canadian High Arctic marine surface waters and snowpacks, Environ. Sci. Technol., 41, 6433-6441, 2007.

Stocker, J., Scheringer, M., Wegmann, F., and Hungerbühler, K.: Modeling the Effect of Snow and Ice on the Global Environmental Fate and Long-Range Transport Potential of Semivolatile Organic Compounds, Env. Sci. Technol., 41, 6192-6198, 2007.

Strode, S. A., Jaeglé, L., Selin, N. E., Jacob, D. J., Park, R. J., Yantosca, R. M., Mason, R. P., and Slemr, F.: Air-sea exchange in the global mercury cycle, Global Biogeochem. Cy., 21, GB1017, doi:10.1029/2006GB002766, 2007.

Sunderland, E. M., Krabbenhoft, D. P., Moreau, J. W., Strode, S. A., and Landing, W. M.: Mercury sources, distribution, and bioavailability in the North Pacific Ocean: Insights from data and models, Global Biogeochem. Cy., 23, GB2010, doi:10.1029/2008GB003425, 2009.

Sundqvist, H.: A parameterization scheme for non-convective condensation including prediction of cloud water content, Quart. J. Roy. Meteor. Soc., 104, 677-690, 1978.

Temme, C., Blanchard, P., Steffen, A., Banic, C., Beauchamp, S., Poissant, L., Tordon, R., and Wiens, B.: Trend, seasonal and multivariate analysis study of total gaseous mercury data from the Canadian atmospheric mercury measurement network (CAMNet), Atmos. Environ. 41, 5423-5441, 2007.

Travnikov, O.: Contribution of the intercontinental atmospheric transport to mercury pollution in the Northern Hemisphere, Atmos. Environ., 39, 7541-7548, 2005.
Van Loon, L., Mader, E., and Scott, S. L.: Reduction of the aqueous mercuric ion by sulfite: UV spectrum of $\mathrm{HgSO}_{3}$ and its intramolecular redox reaction, J. Phys. Chem. A., 104, 1621-1626, 2000.

Van Oostdam, J., Donaldson, S. G., Feeley, M., Arnold, D., Ayotte, P., Bondy, G., Chan, L., Dewaily, É., Furgal, C. M., Kuhnlein, H., Loring, E., Muckle, G., Myles, E., Receveur, O., Tracy, B., Gill, U., Kalhok, S.: Human health implications of environmental contaminants in Arctic Canada: A review, Sci. Total Environ., 351-352, 165-246, 2005.

Warren, S. G.: Optical properties of snow, Rev. Geophys. Space Phys., 20, 67-89, 1982.

Warren, S. G., Brandt, R. E., and Grenfell, T. C.: Visible and nearultraviolet absorption spectrum of ice from transmission of solar radiation into snow, Appl. Optics, 45, 5320-5334, 2006.

Wen, D., Lin, J. C., Meng, F., Gbor, P. K., He, Z., and Sloan, J. J.: Quantitative assessment of upstream source influences on total gaseous mercury observations in Ontario, Canada, Atmos. Chem. Phys., 11, 1405-1415, doi:10.5194/acp-11-1405-2011, 2011.

Wennberg, P.: Bromine explosion, Nature, 397, 299-301, 1999.

Wilke, C. R. and Chang, P.: Correlation of diffusion coefficients in dilute solutions, AIChE J., 1, 264-270, doi:10.1002/aic.690010222, 1955.

Witherow, R. A. and Lyons, W. B.: Mercury deposition in a Polar Desert ecosystem, Environ. Sci. Technol., 42, 4710-4716, 2008.

Xiao, Z. F., Munthe, J., Stromberg, D., Lindqvist, O.: Photochemical behavior of inorganic mercury compound in aqueous solution, in Mercury as a Global Pollutant - Integration and Synthesis, edited by: Watras, C. J. and Huckabee, J. W., 581-592, Lewis Publishers, Michigan, USA, 1994.

Yang, X., Pyle, J. A., Cox, R. A., Theys, N., and Van Roozendael, M.: Snow-sourced bromine and its implic'ations for polar tropospheric ozone, Atmos. Chem. Phys., 10, 7763-7773, doi:10.5194/acp-10-7763-1020, 2010.

Yue, W., Meneveau, C., Parlange, M. B., Zhu, W., Kang, H. S., and Katz, J.: Turbulent kinetic energy budgets in a model canopy: comparisons between LES and wind-tunnel experiments, Environ. Fluid Mech., 8, 73-95, 2008.

Zhang, L., Gong, S., Padro, J., and Barrie, L. A.: A size-segregated particle dry deposition scheme for an atmospheric aerosol module, Atmos. Environ., 35, 549-560, 2001.

Zhang, L., Brook, J. R., and Vet, R.: A revised parameterization for gaseous dry deposition in air-quality models, Atmos. Chem. Phys., 3, 2607-2082, doi:10.5194/acp-3-2067-2003, 2003. 